\title{
OVERVIEW OF RECENT GEOLOGIC FIELD INVESTIGATIONS, NORTH SLOPE AND BROOKS RANGE FOOTHILLS, ALASKA
}

\author{
by
}

\author{
Marwan A. Wartes ${ }^{1}$ and Paul L. Decker ${ }^{2}$
}

\section{INTRODUCTION}

In recent years, the Alaska Department of Natural Resources (DNR) has pursued a leadership role in advancing the understanding of North Slope geology and petroleum systems, primarily through stratigraphic studies and geologic mapping in the foothills of the northern Brooks Range (fig. 1). The North Slope Energy Program was developed in response to the need for high quality, publicly available geologic data to stimulate exploration for hydrocarbons in northern Alaska. Directed by the Division of Geological \& Geophysical Surveys (DGGS), this program is a multi-agency collaboration with geologists and geophysicists from the Division of Oil \& Gas (DOG), the United States Geological Survey (USGS), and the University of Alaska Fairbanks (UAF), among others.

In addition to original geological studies, we also led an annual two-day field trip aimed at highlighting key exposures that provide insight into the geologic evolution of the North Slope petroleum system. In 2007, this tour took place on June 29 and 30 and was attended by 21 geologists from seven oil and gas companies, in addition to geologists and directors from DGGS, DOG, and USGS. The summary presentation provided to attendees is included here as Appendix A-1.

This volume of collected papers is intended to offer timely summaries of recent data and interpretations (fig. 1 shows location of each study area). Some of the topics covered in papers in this volume include data acquired prior to the 2007 season. All of these reports are based in part on preliminary field evidence; final interpretations await additional analytical data, particularly biostratigraphic information.

\section{PROJECT STAFF}

In order to achieve our program objectives, we annually assemble a team with a cross-section of expertise sufficient to address topics relevant to understanding of the petroleum system in northern Alaska. During 2007, the following geologists participated in various aspects of field and/or analytical work, some of which are presented in various papers included in this volume:

Marwan Wartes (DGGS) —Clastic sedimentology, basin analysis, and tectonics Paul Decker (DOG) — Stratigraphy, structural geology, and petroleum geology

David LePain (DGGS) — Clastic sedimentology and sequence stratigraphy

Robert Gillis (DGGS) —Structural geology and thermochronology

Rocky Reifenstuhl (DGGS) - Reservoir quality and geologic mapping

Robert Swenson (DGGS) - Structural geology and petroleum geology

Wes Wallace (UAF)—Structural geology, tectonics, and geologic mapping

C. Gil Mull (Consultant)—Regional geology

Paige (Peapples) Delaney (DGGS) —Structural geology and geologic mapping

Andrea Loveland (DGGS) — Structural geology and geologic mapping

Ken Helmold (DOG) — Reservoir quality and basin modeling

Diane Shellenbaum (DOG) — Seismic stratigraphy and data processing

Peter Flaig (UAF, Ph.D student) — sedimentology and stratigraphy

Dolores van der Kolk (DGGS/UAF, MS student)—sedimentology and stratigraphy

Jacob Mongrain (DGGS/UAF, Ph.D student)—sedimentology and stratigraphy

In addition, we also benefitted from informal collaboration with several USGS geologists engaged in petroleum-related geological research in northern Alaska, including David Houseknecht, Tom Moore, Chris Schenk, and Chris Potter.

\footnotetext{
${ }^{1}$ Alaska Division of Geological \& Geophysical Surveys, 3354 College Rd., Fairbanks, Alaska 99709-3707

Email for Marwan A. Wartes: marwan.wartes@alaska.gov

${ }^{2}$ Alaska Division of Oil \& Gas, 550 W. 7th Ave., Suite 800, Anchorage, Alaska 99501-3560
} 

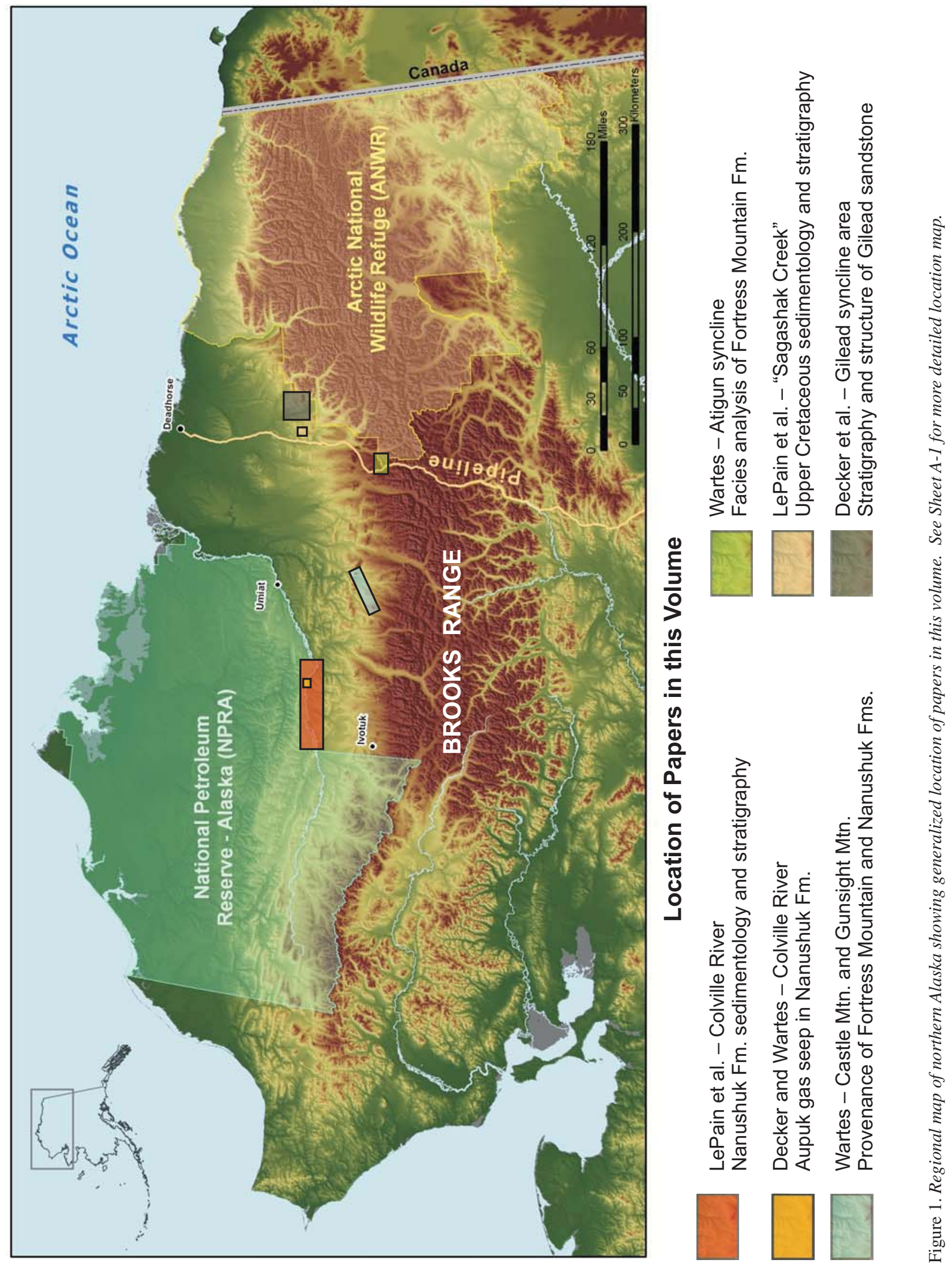


\section{SUMMARY OF 2007 FIELD PROGRAM}

In 2007, our team was based out of a temporary camp near Galbraith Lake from June 15 through July 10 (Sheet A-1). The majority of our work was helicopter supported and ranged from daily flights to multi-day spike camps that were deployed to remote locations. Sheet A-1 illustrates the coverage of our $\sim 700$ different field stations. In addition to sedimentologic and structural observations, an extensive selection of samples were collected, most of which require contracted analytical work. The results of these analyses were not yet available for inclusion in this volume, although subsequent publications will incorporate these data. Samples were collected for the following purposes:

- $\quad$ Lithology (representative)

- Thin sections

- $\quad$ Porosity and permeability

- RockEval and total organic carbon

- Vitrinite reflectance

- Hydrocarbon extract and biomarker typing

- Megafossil paleontology

- Microfossil paleontology (foraminifera and palynology)

- Whole-rock geochemistry

- Geochronology (tuff and bentonite)

- Apatite fission track thermochronology

- Detrital zircon geochronology

The following summary of our 2007 field work is intended to be a brief review; more detailed data and interpretations either appear within the papers in this volume, or will be expanded upon in future reports. The focus for our 2007 field studies can be geographically subdivided into a northern and southern belt (Sheet A-1) and are discussed below accordingly.

\section{Northern Belt (Cretaceous strata of the south-central Sagavanirktok Quadrangle)}

Previous reconnaissance work and stratigraphic studies by DGGS have documented a number of important exposures of Cretaceous strata between the Toolik and Echooka rivers (Sheet A-1). These outcrops expose several Brookian depositional sequences in a compact area and provide valuable insight into the time-transgressive northeastward progradation of genetically related shelf, slope, and deepwater facies. Through increased collaboration with DOG geologists, we have begun integrating detailed outcrop observations with available well and two-dimensional (2-D) seismic data, greatly increasing the robustness of our stratigraphic correlations and regional geologic models.

- $\quad$ Preliminary Sagavanirktok River Area Geologic Mapping —We have received state and federal funding to conduct a STATEMAP project in 2008 in the south-central Sagavanirktok Quadrangle (Sheet A-1). In preparation for this detailed (1:63,360-scale) mapping effort, we conducted reconnaissance work during the 2007 season. The area contains a number of large east-west-trending folds with uncertain gas prospectivity, but has never been mapped in detail (see Mull [1989] for 1:250,000-scale "strip maps” along the Dalton Highway). Our preliminary work helped identify geologically reasonable map borders and highlighted stratigraphic nomenclature issues. In particular, the stratigraphy of this map area is transitional between the Umiat area, where the formation designations largely focus on proximal units, and the Canning River area, which includes correlative distal units, but with differing stratigraphic nomenclature (Molenaar and others, 1986; Mull and others, 2003).

- Gilead sandstone (Torok Formation)_-Tertiary uplift of the northeastern Brooks Range has locally exposed the lower parts of the Brookian Sequence along the Phillip Smith mountain front (Pessel and others, 1990). These rocks include the Albian-Cenomanian Gilead sandstone (informal name), which provides unique insight into the early evolution of the basin that is largely concealed in the subsurface to the west (Reifenstuhl, 1991). To improve our understanding of the stratigraphy and structure of this area, a number of traverses were conducted during the 2007 field season along the Ivishak River, Gilead Creek, and across Gilead syncline (Sheet A-1). Our preliminary interpretations, summarized in Decker and others (2008), suggest that Albian to Turonian depositional environments near the southeastern 
margin of the Colville foreland basin may have been significantly different from the time-equivalent stratigraphic record farther west in the Umiat and Tarn/Meltwater areas.

- Terminal Nanushuk shelf edge-The terminal shelf edge of the easterly prograding Albian-Cenomanian Nanushuk-Torok depositional system is well defined by seismic and well log correlations in the area north of the Umiat baseline near the Itkillik River, some $80 \mathrm{~km}$ west of the Dalton Highway (for example, Houseknecht and Schenk, 2005). However, this depositional system also included a northerly prograding topset sequence derived from the Brooks Range that extended much farther east across the present-day foothills province (Molenaar, 1988; Huffman and others, 1988). The northern limit of the Nanushuk Formation within this transverse component of the system is very poorly known due to limited exposure, complex structure, and the lack of publicly available subsurface data. The Torok Formation is exposed along the Dalton Highway at a locality named "Ice Cut" (Mull, 1989; Sheet A-1). During the 2007 field season, we visited an enigmatic exposure of loosely consolidated pebble conglomerate and sandstone exposed east-northeast of Ice Cut. This isolated outcrop includes locally channelized facies that are not typical of the deepwater Torok Formation in this area, most notably with respect to grain size. On the basis of reconnaissance mapping, we suspect these gravels lie in the footwall of a thrust fault and may represent a preserved remnant of the most northerly Nanushuk topset facies. Whether part of the Nanushuk, Torok, or conceivably the Tuluvak Formation, this exposure has significant implications for paleogeographic, depositional environment, and thrust reconstructions, particularly with respect to the type and extent of prospective reservoirs in this area. More work is needed to evaluate multiple hypotheses that might explain this anomalous exposure.

- Seabee Formation - In outcrop, the Seabee Formation has been fairly well defined in the Umiat area (for example, Houseknecht and Schenk, 2005; Mull and others, 2004). However, despite significant hydrocarbon discoveries in more distal facies, such as the informally named Bermuda interval (Alaska Oil and Gas Conservation Commission, 1998; 2001), limited work has been published correlating the unit basinward to the east (Decker, 2007). During 2001, 2002, and 2007, D. LePain and colleagues conducted detailed sedimentologic work on Turonian-Campanian strata discontinuously exposed along an unnamed tributary between the Sagavanirktok and Ivishak rivers. We informally refer to this drainage as "Sagashak Creek" (Sheet A-1). Despite significant stretches of cover, we have been able to construct a composite stratigraphy along this traverse encompassing approximately 2,450 m of Upper Cretaceous section (LePain and others, 2008a). On the basis of biostratigraphic control, correlation with available subsurface data, and facies considerations, the lower portion of this section is designated as Seabee Formation and is interpreted as proximal basin-floor(?)-base-of-slope deposits (LePain and others, 2008a, this volume; 2008c).

We also revisited an exposure on the Sagavanirktok River, just downstream from the confluence with the Lupine River (Sheet A-1; see also LePain and others, 2002). This sandstone and shale section was originally mapped as Nanushuk Formation by Mull (1989). However, recent revisions to Cretaceous stratigraphic nomenclature (Mull and others, 2003) restrict the Nanushuk Formation to seismic topset facies. Based on the sedimentary facies at this location, such as the prevalence of sediment gravity flows, we presently interpret the section as dominantly deepwater deposits, of either the Cenomanian upper Torok Formation or Turonian Seabee Formation, or perhaps spanning the contact between these two units. This interpretation is supported by the locally abundant bentonite, tuff, and apparent tuffaceous sandstone, all of which are characteristic of Upper Cretaceous units. We are awaiting biostratigraphic analyses to assist formation designation and more precise ties to the nearby Lupine well (Sheet A-1).

- Hue Shale-At the type locality along Hue Creek in ANWR, the Hue Shale includes condensed basinal mudstone, bentonites, and tuff ranging from Aptian to Campanian in age (Molenaar and others, 1987). However, coeval Brookian strata in the central Sagavanirktok Quadrangle are much thicker and include more proximal slope facies of the Seabee and Canning Formations (fig. 2; LePain and others, 2008a). The transitional nature of these facies relationships is well illustrated at one locality along Sagashak Creek (Sheet A-1), where a conspicuous section of organic-rich mudstone and tuffaceous strata are intercalated with more sandstone-rich slope and base-of-slope(?) facies (LePain and others, 2008a). We interpret this as a direct outcrop example of the commonly depicted intertonguing of more proximal units with the condensed Hue shale (fig. 2). This interval was also noteworthy for 
Overview of recent geologic field investigations, North Slope and Brooks Range foothills, Alaska

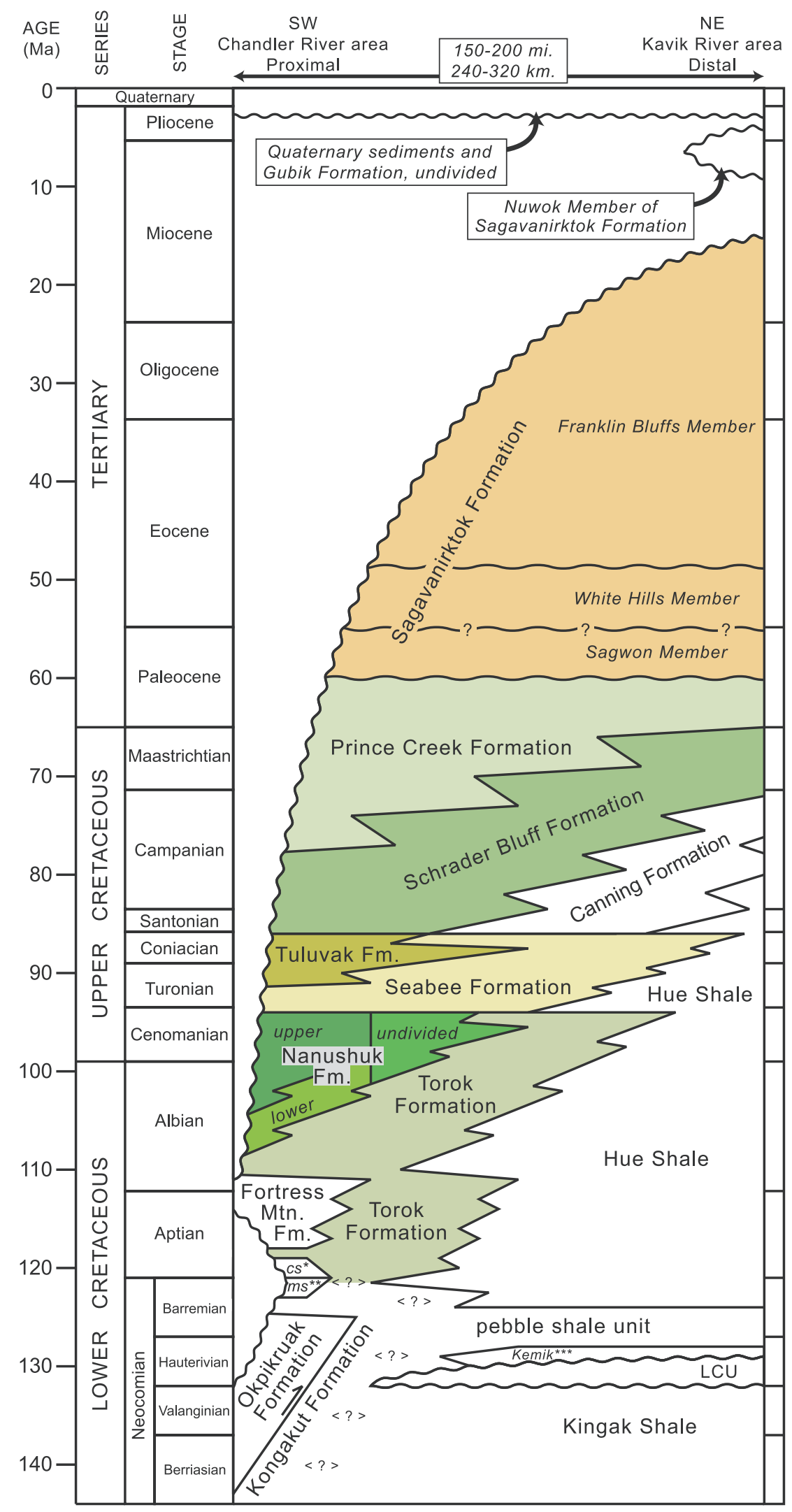

Figure 2. Chronostratigraphic column showing revised Cretaceous and Tertiary stratigraphic nomenclature of Mull and others (2003). cs* = cobblestone sandstone (informal unit) of Fortress Mountain Formation; ms** = manganiferous shale unit (informal). 
its strong hydrocarbon odor within shales and subjacent tuffaceous sandstone beds. The presence of this condensed zone is a potentially useful sequence stratigraphic marker and likely reflects sediment starvation, probably during transgressive and/or highstand conditions.

- Canning Formation - In outcrop, the term Canning Formation has historically been limited to the area east of about the Echooka River (Sheet A-1). Many Santonian-Campanian rocks in the central Sagavanirktok Quadrangle have been assigned instead to the Schrader Bluff Formation (Mull and others, 2003; C.G. Mull, unpublished mapping). However, recent well and seismic correlations indicate that shelfal strata of the lower and middle(?) Schrader Bluff Formation transition eastward into slope-clinoform deposits, and are thus more appropriately ascribed to the Canning Formation (for example, Houseknecht and Schenk, 2005; Decker, 2007). This is supported by biostratigraphic data and facies interpretations from Sagashak Creek area, where the Canning Formation is interpreted to overlie the Seabee Formation (LePain and others, 2008a, this volume; 2008c).

- Prince Creek and Schrader Bluff Formations - In 2007, we measured sections in the Schrader Bluff Formation at three localities. From west to east (proximal to distal) these sections were along the Toolik River, Sagashak Creek, and the Ivishak River (Sheet A-1). Detailed outcrop observations for the Sagashak section are reported in LePain and others (2008a), where the upward transition from upper slope Canning Formation into shelfal Schrader Bluff can be documented. An additional section measured along the Ivishak River expanded upon on earlier work by LePain in 1999, characterizing depositional environments ranging from distributary mouth bars and channels to stacked coarsening- and thickening-upward delta lobes. UAF graduate students Peter Flaig and Dolores van der Kolk collected detailed sedimentologic and stratigraphic data along the Toolik River where they documented intercalations of nonmarine coal-bearing facies of the Prince Creek Formation with shallow marine rocks of the Schrader Bluff Formation. Similar intertonguing relationships are interpreted in the subsurface (Decker, 2007). Subsequent work will seek to correlate these three exposures and consider their evolution in a sequence stratigraphic context.

\section{Southern Belt (proximal synorogenic foreland basin facies)}

Lower Cretaceous rocks in the Brooks Range foothills possess significant potential for large oil and gas accumulations, particularly shallow marine and turbidite facies of the Nanushuk-Torok system (for example, Houseknecht, 2003). Recent leasing activity, the potential opening of additional acreage in southern NPRA, and the move toward commercialization of North Slope gas all underscore the significance of this underexplored interval. During the 2007 field season, we continued a number of ongoing stratigraphic studies of Lower Cretaceous rocks in the foothills. The complex structural evolution of the foothills results in an increased exploration risk associated with maturation, migration, and trap formation. Therefore, the program also continued to evaluate the structural geology of the inner Brooks Range foothills (south of the Tuktu escarpment shown on Sheet A-1), documenting the geometry and style of deformation.

- Geologic Mapping in the Proximal Foreland Basin-In recent years, DGGS has conducted detailed (1:63,360-scale) geologic mapping across the central Brooks Range foothills, just north of the mountain front (for example, Peapples and others, 2007; Harris and others, 2002). Due to the complexity of the geology in this area, there remain significant unresolved questions that limit our ability arrive at a coherent structural/stratigraphic model for the evolution of the area. Our main focus in 2007 was along Peregrine Ridge, Section Creek, and Accomplishment Creek (Sheet A-1). This new detailed mapping data will be integrated with previous work to help develop a more regionally consistent framework.

- Burial History in the Proximal Foreland Basin-Recent geologic mapping, stratigraphic studies, thermal maturity data, and thermochronologic constraints have led us to conclude that a significant portion of the proximal foreland basin was deposited on top of the orogenic wedge-including the entire belt marked by the Early Cretaceous Fortress Mountain Formation. This observation suggests that an extensive Early Cretaceous wedge-top depozone (in the sense of DeCelles and Giles, 1996) existed in the southern Colville foreland basin. Syndepositional deformation within this zone may have promoted persistent structural highs that limited accommodation and thus burial (Wartes and Swenson, 2005). This model of foreland basin development partly explains anomalously low thermal maturity values observed by other studies along the Brooks Range foothills (for example, Cole and 
others, 1997; Mull and others, 2000). In order to test the wedge-top model, we collected a number of apatite fission track samples in 2007 from the Cobblestone Creek area. This region was selected in light of prior data that indicated abrupt northward increase in mid to Late Cretaceous stratigraphic burial (Mull and others, in review). Ultimately, future oil and gas exploration in the foothills will benefit from a basin model that can accurately predict burial history and maturation.

- Okpikruak Formation-Although the Berriasian-Valanginian Okpikruak Formation is unlikely to represent a viable reservoir interval, the unit does represent our only stratigraphic window into the early Neocomian record of foreland basin evolution. In 2007, we investigated several exposures in the Section Creek area (Sheet A-1). The northeastern Brooks Range has undergone significant Tertiary exhumation and, as a result, this is the only area where the Early Cretaceous orogenic wedge and overlying basal foreland basin strata are well exposed in long, coherent sections. Formation and age designations remain problematic in these rocks, although we discovered several new occurrences of the key Valanginian coquinoid limestone marker bed. We also anticipate having improved criteria following biostratigraphic analyses and further petrographic examinations.

- Phosphatic/Manganiferous Shale-This informal stratigraphic unit remains enigmatic, despite its unique lithofacies that includes a conspicuous reddish-brown, metallic-weathering sheen. The unit underlies the cobblestone sandstone member of the Fortress Mountain Formation and is best known from the Cobblestone Creek area (Sheet A-1; Mull and others, in review). The unusual shale may record the change in basin polarity (sediment dispersal direction) and the onset of Brookian deposition in this area, north of the advancing allochthons and Okpikruak flysch deposits. On the basis of stratigraphic position and limited biostratigraphic control, we speculate that the unit is correlative with the Kongakut Formation and Barremian Pebble Shale unit to the north (fig. 2). To allow better evaluation of these hypotheses, detailed sedimentologic data were collected in 2007 from the best-exposed section along Cobblestone Creek. The interpreted correlation with the Pebble Shale was supported by the first reported discovery of numerous outsized granules, pebbles, and cobbles floating within the shale. Further characterization of this interval awaits analytical data from newly collected petrographic, geochemical, and micropaleontology samples.

- Cobblestone Sandstone-The Aptian(?) Cobblestone Sandstone member of the Fortress Mountain Formation locally records the earliest sandstone deposition in the proximal foreland basin (Mull and others, in review). However, this distinctive lighter-weathering graywacke has not been recognized west of the Kanayut River (Harris and others, 2004). In 2007, we visited several key exposures of amalgamated sediment gravity flow deposits to collect additional sedimentologic and stratigraphic information. Most notably, an exposure along the Nanushuk River (Sheet A-1) included an unusual association of facies including poorly sorted conglomerate and breccia. The texturally immature facies, and clast composition were indistinguishable from a syntectonic unit we termed "Kfmv" in recent mapping farther west in the Siksikpuk River area (Peapples and others, 2007). This observation supports our earlier speculation that the two units are correlative and likely represent gradational facies equivalents of one another. If additional data further substantiate this interpretation, it will allow us to construct a more coherent model for basin evolution in this wedge-top environment (for example, Wartes and Swenson, 2005).

- Fortress Mountain Formation-DGGS has supported several years of stratigraphic research on the Fortress Mountain Formation, resulting in refined depositional environment interpretations and stratigraphic correlations (at the local to sub-regional scales). An example of this work from the Atigun syncline area is included in this volume (fig. 1; Sheet A-1; Wartes, 2008a, this volume). In collaboration with the USGS, another publication on the stratigraphy of the Fortress Mountain in the Siksikpuk River area should be published imminently (Houseknecht and others, 2007).

We conducted additional stratigraphic reconnaissance and sampling in 2007 near Toolik Lake (Sheet A-1). These are the northernmost exposures of the Fortress Mountain Formation in this area and have the potential to clarify the basinward evolution of this part of the clastic wedge. In particular, it remains unclear how this part of the upper(?) Fortress Mountain Formation relates to nearby exposures of the Nanushuk Formation. This important stratigraphic question is further addressed in another chapter in this volume through a comparison of detrital zircon ages within the two units (fig. 1; Wartes, 2008b, this volume). 
- Nanushuk Formation-DGGS has led a multi-year, outcrop-based investigation of the sequence stratigraphy and reservoir potential of the Nanushuk Formation. This work has resulted in numerous detailed measured sections throughout the central Brooks Range foothills and greatly improved our understanding of this depositional system. A major publication summarizing a substantial part of our Nanushuk investigations is now complete (LePain and others, 2008d) and will be released shortly after the publication of this volume. In addition to sequence stratigraphic analyses, this milestone synthesis includes a comprehensive summary of Nanushuk lithofacies, facies associations, ichnology, micropaleontology, and regional depositional environments. During 2007, we conducted limited follow-up work on the Nanushuk at Slope Mountain (Sheet A-1). Our main focus was revisiting a significant intraformational sequence boundary and better documenting the overlying facies association and erosional relief on the unconformity (LePain and others, 2008d).

We have also extended our Nanushuk studies westward in recent years, examining well exposed sections along the Colville River (fig. 1). Based on facies analysis, these exposures appear to reflect the development of river-dominated deltas, contrasting with the more pervasive wave influence observed to the east (for example, LePain and others, 2006; Huffman and others, 1988). These measured sections and preliminary correlations with publicly available seismic data are summarized in LePain and others (2008b) in this volume.

During our work along the Colville River, we sampled a gas seep in the Nanushuk Formation near the mouth of Aupuk Creek (fig. 1). Based on new geochemical data from this seep, we were able to demonstrate the gas is thermogenic in origin and likely represents condensate- or oil-associated gas generated at oil-window maturity. These results are included in Decker and Wartes (2008, this volume).

\section{SUMMARY}

The above discussion is intended only as a preliminary progress report that provides a brief introduction to recent field investigations, particularly during 2007. This volume is an effort to execute a rapid turn-around of many of our observations and preliminary interpretations, rather than delay distribution of data until all results are in. Additional work will be published as analytical data become available and as stratigraphic and structural interpretations continue to mature.

\section{ACKNOWLEDGMENTS}

This review incorporated the work of the entire geoscience team associated with the DNR North Slope Program (listed under project staff in the text). C.G. Mull deserves special mention-much of our work would not be possible without the geological framework he established during decades of field work in northern Alaska. D. LePain provided a helpful review of this manuscript. Finally, J. Robinson and P. Davis are thanked for their tireless editorial work in preparing this volume for publication.

Fieldwork was supported through a combination of state budget sources and substantial contributions from companies and individuals involved in the Alaska oil and gas industry. Recent sponsors included Anadarko Petroleum Corp., BG Alaska, Chevron, ConocoPhillips Alaska, Inc., ENI, Petro-Canada, Pioneer Natural Resources, Repsol YPF Exploration and Production Co., Shell International Exploration and Production Co., and Talisman Energy, Inc.

\section{REFERENCES}

Alaska Oil and Gas Conservation Commission, 1998, Conservation Order No. 430 (Tarn Pool Rules): Anchorage, AK, 7 p.

2001, Conservation Order No. 456 (Meltwater Pool Rules): Anchorage, AK, 9 p.

Cole, F.E., Bird, K.J., Toro, J., Roure, F., O’Sullivan, P.B., Pawlewicz, M.J., and Howell, D.G., 1997, An integrated model for the frontal Brooks Range and Colville Basin $250 \mathrm{~km}$ west of the Trans-Alaska Crustal Transect: Journal of Geophysical Research, v. 102, p. 20,685-20,708.

DeCelles, P.G., and Giles, K.A., 1996, Foreland basin systems: Basin Research, v. 8, p. 105-123. 
Decker, P.L., 2007, Brookian sequence stratigraphic correlations, Umiat Field to Milne Point Field, west-central North Slope, Alaska: Alaska Division of Geological \& Geophysical Surveys Preliminary Interpretive Report 2007-2, 19 p., 1 sheet.

Decker, P.L., and Wartes, M.A., 2008, Geochemistry of the Aupuk gas seep along the Colville River-Evidence for a thermogenic origin, in Wartes, M.A., and Decker, P.L., eds., Preliminary results of recent geologic field investigations in the Brooks Range foothills and North Slope, Alaska: Alaska Division of Geological \& Geophysical Surveys Preliminary Interpretive Report 2008-1, p. 47-53.

Decker, P.L., Wartes, M.A., Wallace, W.K., Houseknecht, David, Schenk, Christopher, Gillis, R.J., and Mongrain, Jacob, 2008, Stratigraphic and structural investigations in the Ivishak River and Gilead Creek areas: Progress during 2007, in Wartes, M.A., and Decker, P.L., eds, Preliminary results of recent geologic field investigations in the Brooks Range foothills and North Slope, Alaska: Alaska Division of Geological \& Geophysical Surveys Preliminary Interpretive Report 2008-1, p. 55-83, 1 sheet, measured section.

Harris, E.E., Mull, C.G., Montayne, S., and Reifenstuhl, R.R., 2002, Geologic map of the Dalton Highway (Atigun Gorge to Slope Mountain) area, southern Arctic Foothills, Alaska: Alaska Division of Geological \& Geophysical Surveys Preliminary Interpretive Report 2002-2, 1 sheet, scale 1:63,360.

Harris, E.E., Mull, C.G., Peapples, P.R., LePain, D.L., and Burns, P.A., 2004, New detailed (1:63,360-scale) mapping of the Brooks Range northern foothills and rangefront, Kanayut River area, Alaska: AAPG Abstracts with Programs, v. 13, p. 58-59.

Houseknecht, D.W., 2003, Brookian stratigraphic plays in the National Petroleum Reserve-Alaska (NPRA): U.S. Geological Survey Open-File Report 2003-039, 19 p.

Houseknecht, D.W, and Schenk, C.J., 2005, Sedimentology and sequence stratigraphy of the Cretaceous Nanushuk, Seabee, and Tuluvak Formations exposed on Umiat Mountain, north-central Alaska, in Haeussler, P., and Galloway, J.P., eds., Studies by the U.S. Geological Survey in Alaska, 2004, U.S. Geological Survey Professional Paper 1709B, 18 p., 1 plate.

Houseknecht, D.W., Schenk, C.J., and Wartes, M.A., 2007, Sedimentology and sequence stratigraphy of the Lower Cretaceous Fortress Mountain and Torok Formations exposed along the Siksikpuk River, north-central Alaska, in Haeussler, Peter J., and Galloway, John P., eds., Studies by the U.S. Geological Survey in Alaska, 2006: U.S. Geological Survey Professional Paper 1739-D, 27 p., 1 plate.

Huffman, A.C., Jr., Ahlbrandt, T.S., and Bartsch-Winkler, Susan, 1988, Sedimentology of the Nanushuk Group, North Slope, in Gryc, George, ed., Geology and exploration of the National Petroleum Reserve in Alaska, 1974 to 1982: U.S. Geological Survey Professional Paper 1399, p. 281-298.

LePain, D.L., Decker, P.L., and Wartes, M.A., 2008a, Turonian-Campanian strata east of the Trans-Alaska Pipeline corridor, North Slope foothills, Alaska: Progress during the 2001-02 and 2007 field seasons, in Wartes, M.A., and Decker, P.L., eds, Preliminary results of recent geologic field investigations in the Brooks Range foothills and North Slope, Alaska: Alaska Division of Geological \& Geophysical Surveys Preliminary Interpretive Report 2008-1, p. 85-134.

LePain, D.L., Decker, P.L., and Wartes, M.A., 2008b, Measured sections and preliminary interpretations of the Nanushuk Formation exposed along the Colville River near the confluences with the Awuna and Killik rivers, in Wartes, M.A., and Decker, P.L., eds, Preliminary results of recent geologic field investigations in the Brooks Range foothills and North Slope, Alaska: Alaska Division of Geological \& Geophysical Surveys Preliminary Interpretive Report 2008-1, p. 41-45, 4 sheets.

LePain, D.L., Decker, P.L., Wartes, M.A., Gillis, R.J., Mongrain, J.R., Kirkham, R., and Shellenbaum, D.P., 2008c, Sedimentology and Stratigraphy of Upper Cretaceous strata in the Sagavanirktok River area, east-central North Slope, Alaska: AAPG annual meeting abstracts, in press.

LePain, D.L., McCarthy, P.J., and Kirkham, R. 2006, Variations in facies stacking patterns in storm-influenced delta front and shoreface successions, Nanushuk Formation, central North Slope, Alaska [abs.]: Geological Society of America Abstracts with Program, v. 38, no. 5.

2008d, Sedimentology and sequence stratigraphy of the Nanushuk Formation in the central Brooks Range foothills, northern Alaska: Alaska Division of Geological \& Geophysical Surveys Report of Investigation, in press.

LePain, D.L., Kirkham, R., and McCarthy, P.J., 2002, Shoreline to basin transition (?) in Albian-Cenomanian strata east of the Sagavanirktok River, Brooks Range foothills, Alaska [abs.]: AAPG Pacific Section/SPE Regional Conference, Program and Abstracts, p. 87. 
Molenaar, C.M., Bird, K.J., and Collett, T.S., 1986, Regional correlation sections across the North Slope of Alaska: U.S. Geological Survey Miscellaneous Field Studies 1907, 1 sheet.

Molenaar, C.M., Bird, K.J., and Kirk, A.R., 1987, Cretaceous and Tertiary stratigraphy of northeastern Alaska, in Tailleur, I.L., and Weimer, P., eds., Alaskan North Slope Geology: Pacific Section, Society of Economic Paleontologists and Mineralogists and Alaska Geological Society, Book 50, v. 1, p. 513-528.

Molenaar, C.M., 1988, Depositional history and seismic stratigraphy of Lower Cretaceous rock in the National Petroleum Reserve in Alaska and adjacent areas, in Gryc, G., editor, Geology and exploration of the National Petroleum Reserve in Alaska, 1974-1982: U.S. Geological Survey Professional Paper 1399, p. 593-621.

Mull, C.G., 1989, Road log from Chandalar Shelf (Mile 237.1) to Prudhoe Bay (Mile 414), in Mull, C.G., and Adams, K.E., eds., Dalton Highway, Yukon River to Prudhoe Bay, Alaska: Alaska Division of Geological \& Geophysical Surveys Guidebook 7, v. 1, p. 101-131.

Mull, C.G., Harris, E.E., Reifenstuhl, R.R., and Moore, T.E., 2000, Geologic map of the Coke Basin-Kukpowruk River area, DeLong Mountains D-2 and D-3 quadrangles, northwestern Alaska: Alaska Division of Geological and Geophysical Surveys Report of Investigations 2000-2, 1 sheet, scale 1:63,360.

Mull, C.G, Houseknecht, D.W., and Bird, K.J., 2003, Revised Cretaceous and Tertiary Stratigraphic Nomenclature in the Colville Basin, Northern Alaska: U.S. Geological Survey Professional Paper 1673, 51 p.

Mull, C.G., Houseknecht, D.W., Pessel, G.H., and Garrity, C.P., 2004, Geologic map of the Umiat Quadrangle, Alaska: U.S. Geological Survey Scientific Investigations Map 2817-A, 1 sheet.

Mull, C.G., Harris, E.E., and Peapples, P.R., in review, Geologic map of the Cobblestone Creek-May Creek area, east-central Brooks Range foothills, Alaska: Alaska Division of Geological \& Geophysical Surveys Preliminary Interpretive Report, 1 sheet, scale 1:63,360, and booklet.

Peapples, P.R., Wallace, W.K., Wartes, M.A., Swenson, R.F., Mull, C.G., Dumoulin, J.A., Harris, E.E., Finzel, E.S., Reifenstuhl, R.R., and Loveland, A.M., 2007, Geologic map of the Siksikpuk River area, Chandler Lake Quadrangle, Alaska: Alaska Division of Geological \& Geophysical Surveys Preliminary Interpretive Report 2007-1, 1 sheet.

Pessel, G.H., Robinson, M.S., Clough, J.G., Imm, T.A., Reifenstuhl, R.R., Ryherd, T.J., Myers, M.D., and Mull, C.G., 1990, Preliminary geologic map of the Gilead Creek area, Sagavanirktok A-2 Quadrangle, Arctic Foothills, Alaska: Alaska Division of Geological \& Geophysical Surveys Public-Data File 90-18, 7 p., 1 sheet.

Reifenstuhl, R.R., 1991, Gilead sandstone, northeastern Brooks Range, Alaska; An Albian to Cenomanian marine clastic succession, in Reger, R.D., ed., Short Notes on Alaskan Geology 1991: Alaska Division of Geological \& Geophysical Surveys Professional Report 111, p. 69-76.

Wartes, M.A., 2008a, Measured section and facies analysis of the Lower Cretaceous Fortress Mountain Formation, Atigun Syncline, northern Alaska, in Wartes, M.A., and Decker, P.L., eds, Preliminary results of recent geologic field investigations in the Brooks Range foothills and North Slope, Alaska: Alaska Division of Geological \& Geophysical Surveys Preliminary Interpretive Report 2008-1, p. 11-24, 1 sheet.

Wartes, M.A., 2008b, Evaluation of stratigraphic continuity between the Fortress Mountain and Nanushuk Formations in the Central Brooks Range foothills-Are they partly correlative?, in Wartes, M.A., and Decker, P.L., eds, Preliminary results of recent geologic field investigations in the Brooks Range foothills and North Slope, Alaska: Alaska Division of Geological \& Geophysical Surveys Preliminary Interpretive Report 2008-1, p. 25-39.

Wartes, M.A., and Swenson, R.F., 2005, New constraints on the structural and stratigraphic development of the proximal Colville foreland basin; Implications for burial history and oil and gas exploration in the central Brooks Range foothills, northern Alaska, in GSA, Cordilleran Section, 101st annual meeting: AAPG, Pacific Section, 80th annual meeting, Abstracts with Programs, v. 37, no. 4, p. 92-93. 


\section{Text for reports with appendices:}

This appendix is included in this PDF document for the reader's convenience.

In the full publication, the appendices and sheets are placed at the conclusion of all of the text. The separation of the appendices and sheets from their chapter in the full publication determines the page numbers; thus, you will find that the page numbers for this smaller piece of the larger document are not sequential. 


\section{APPENDIX A-1}

\section{NORTH SLOPE FIELD TOUR}


This page has intentionally been left blank. 


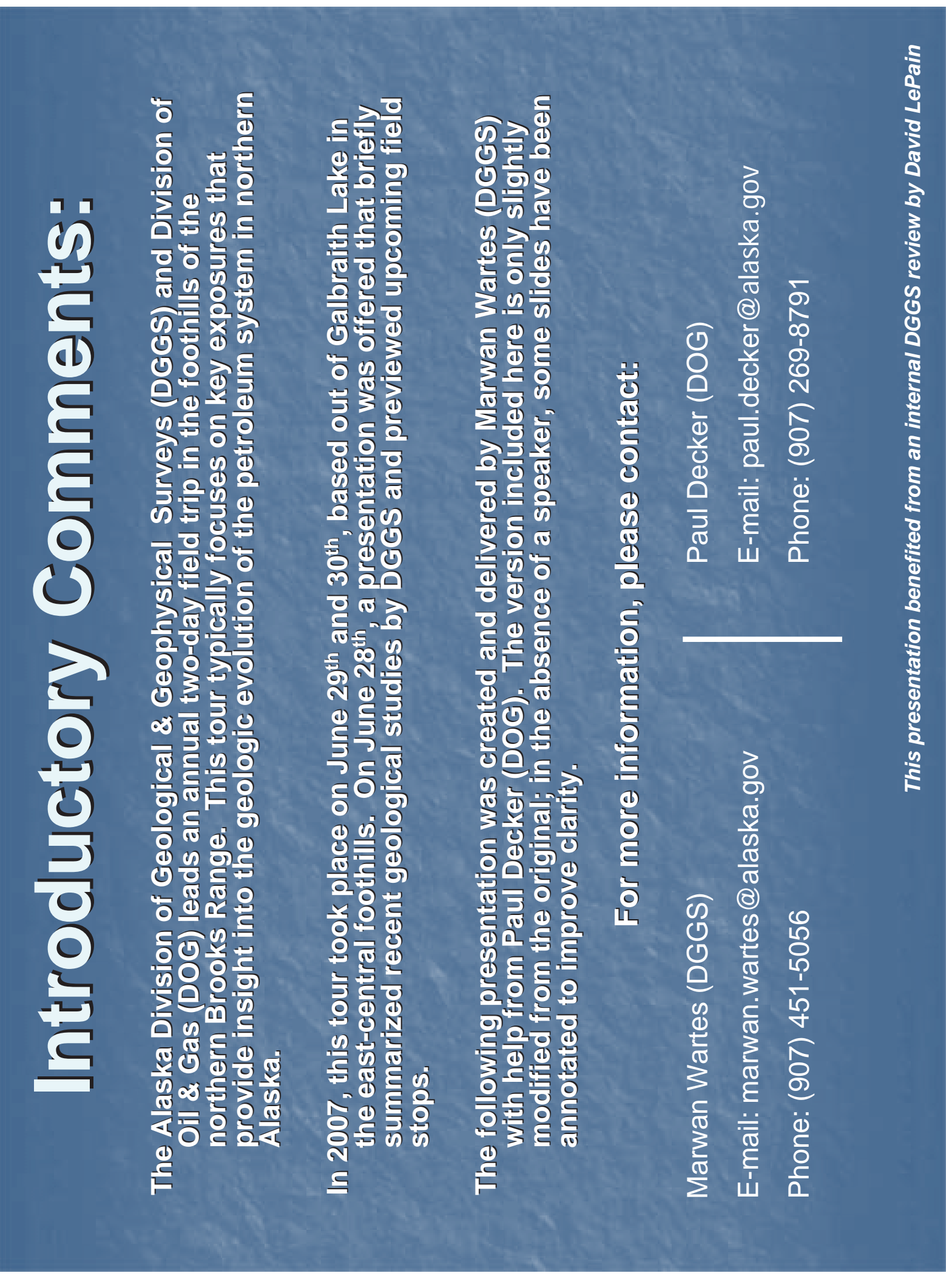




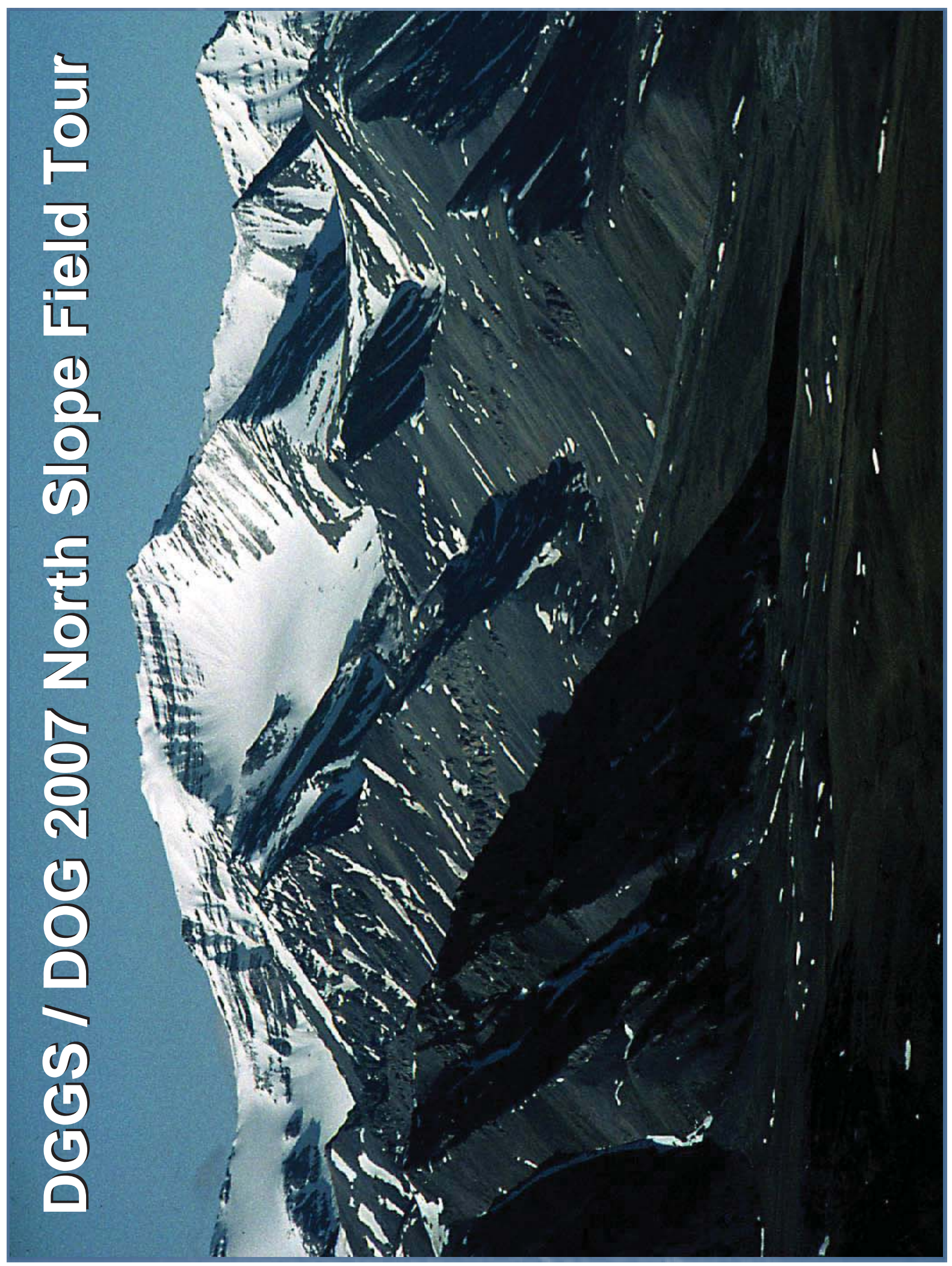




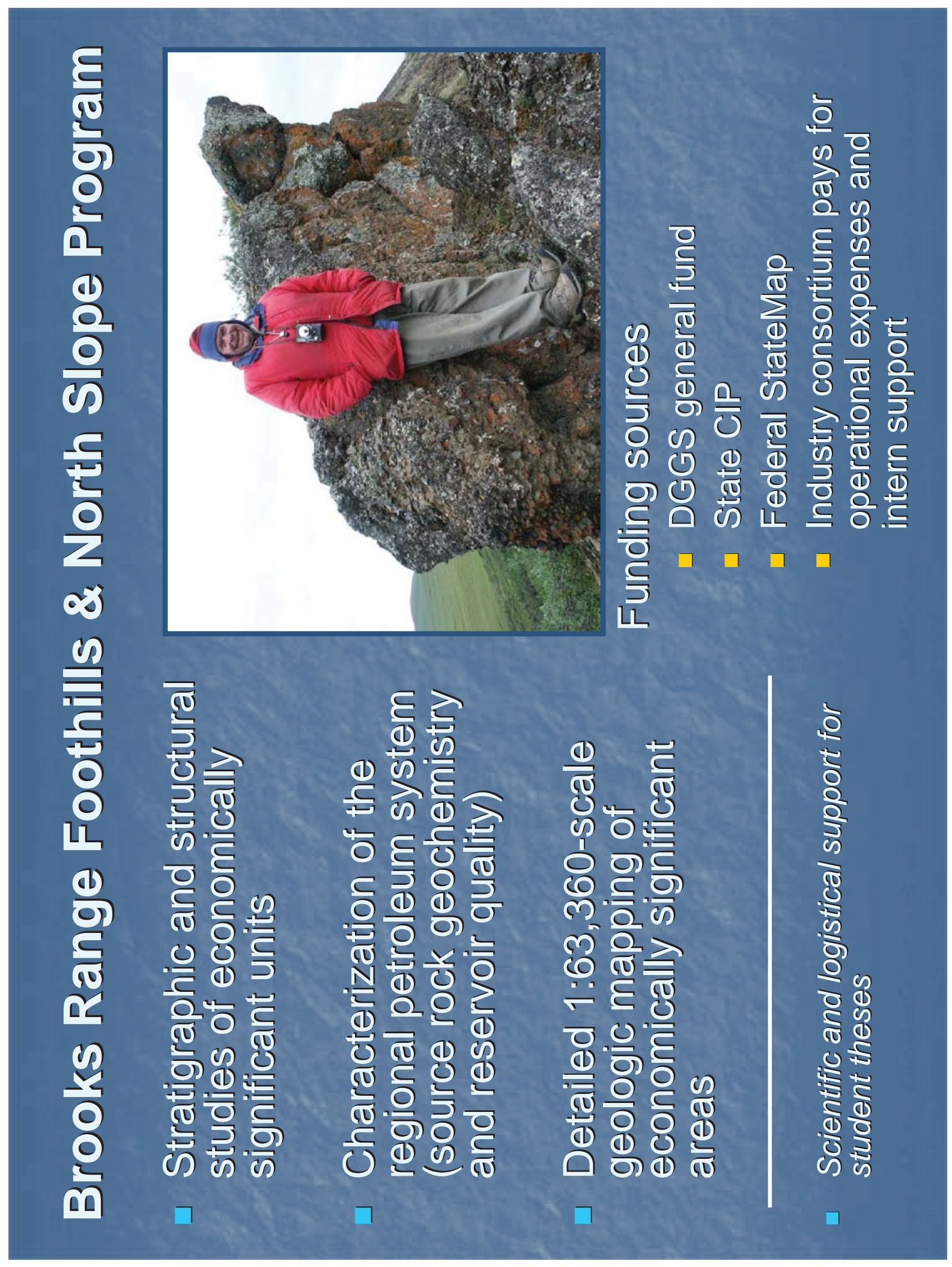




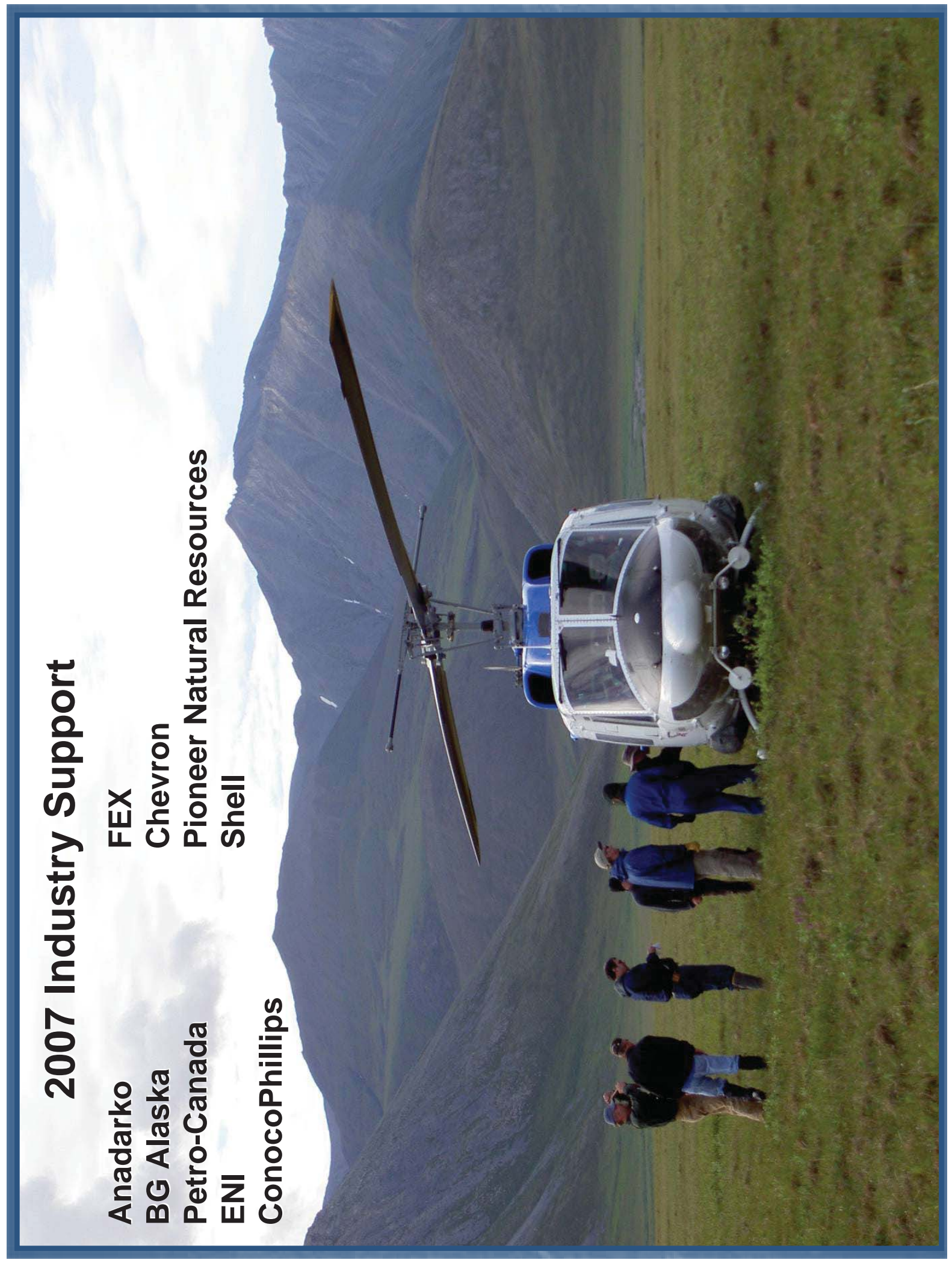



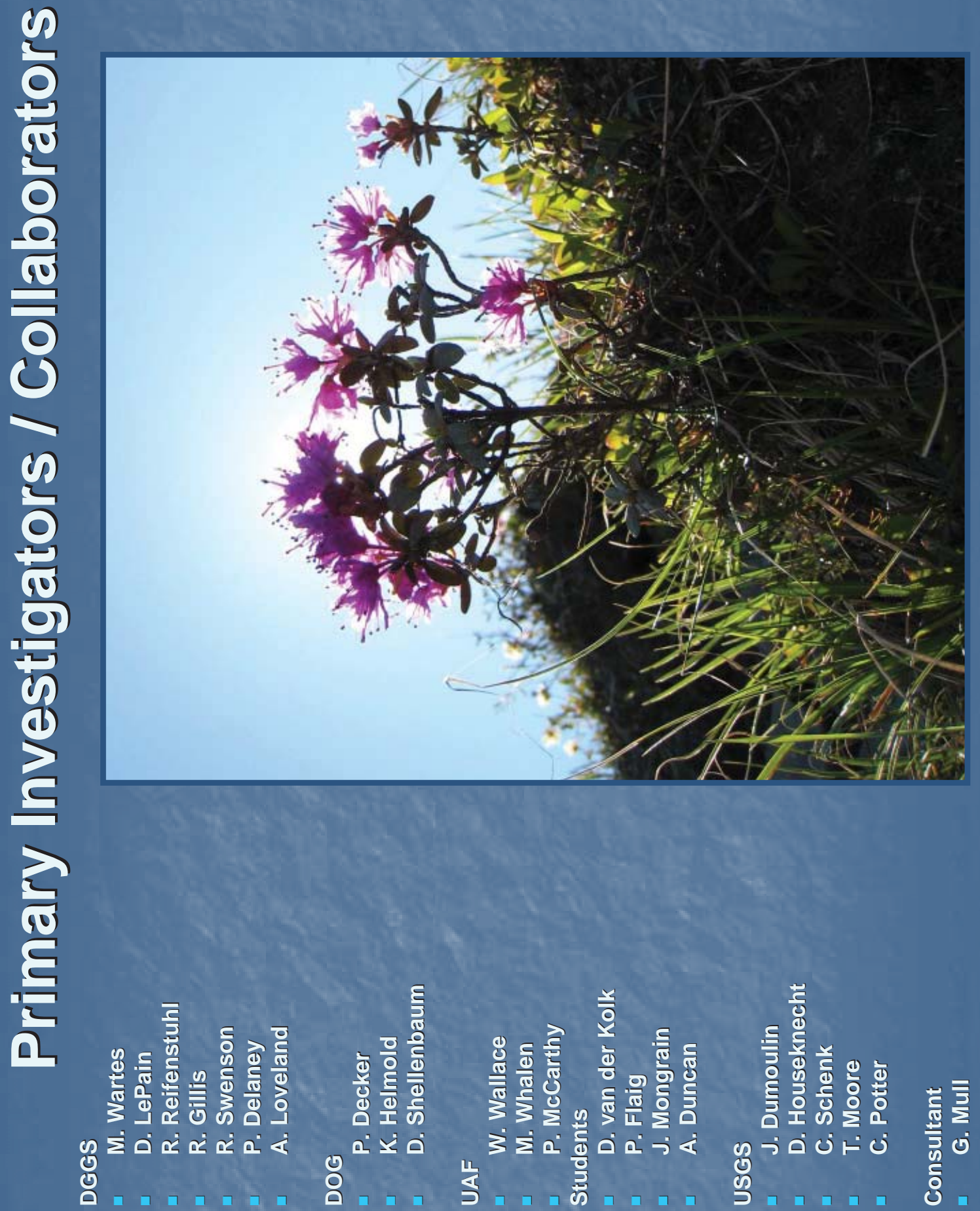

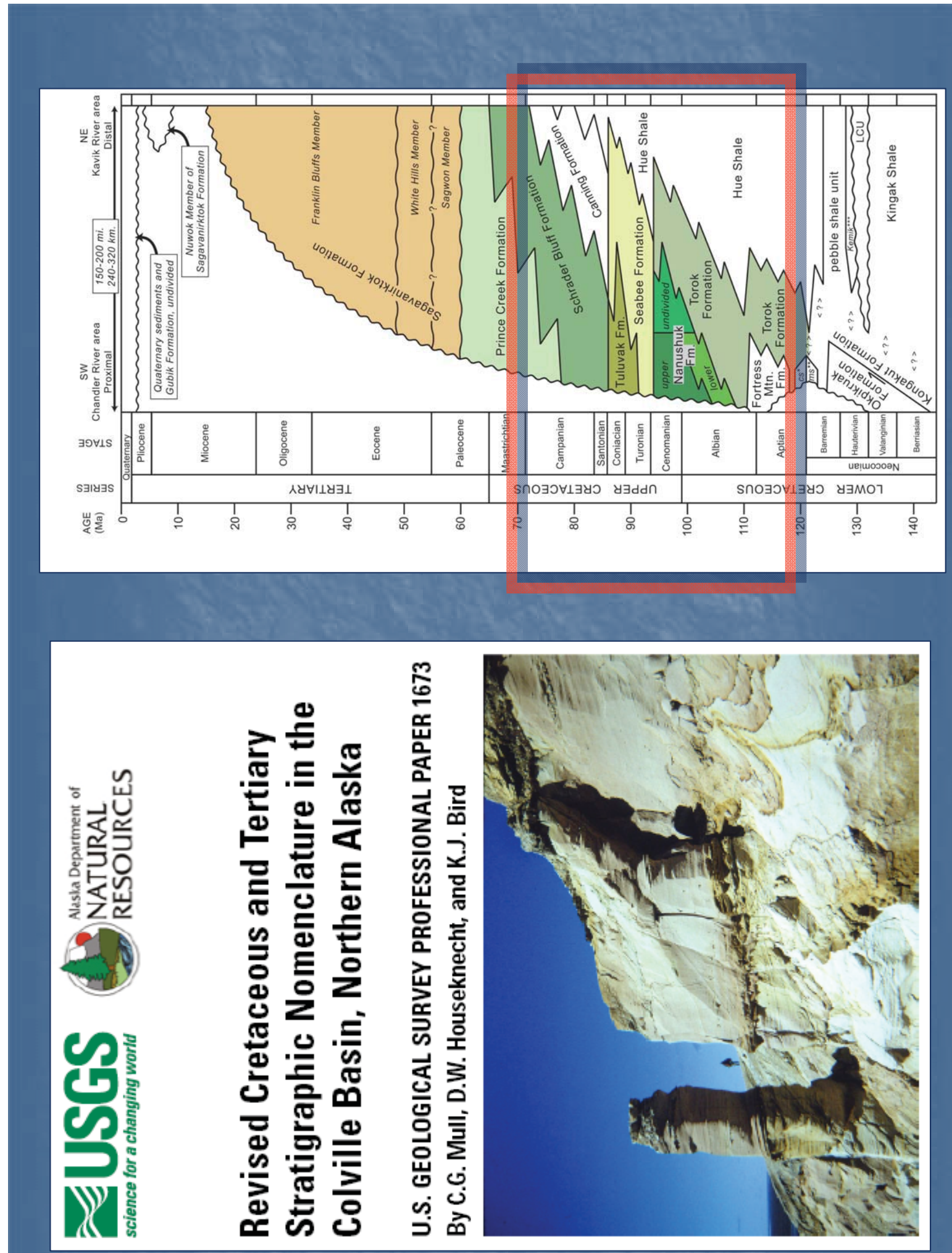


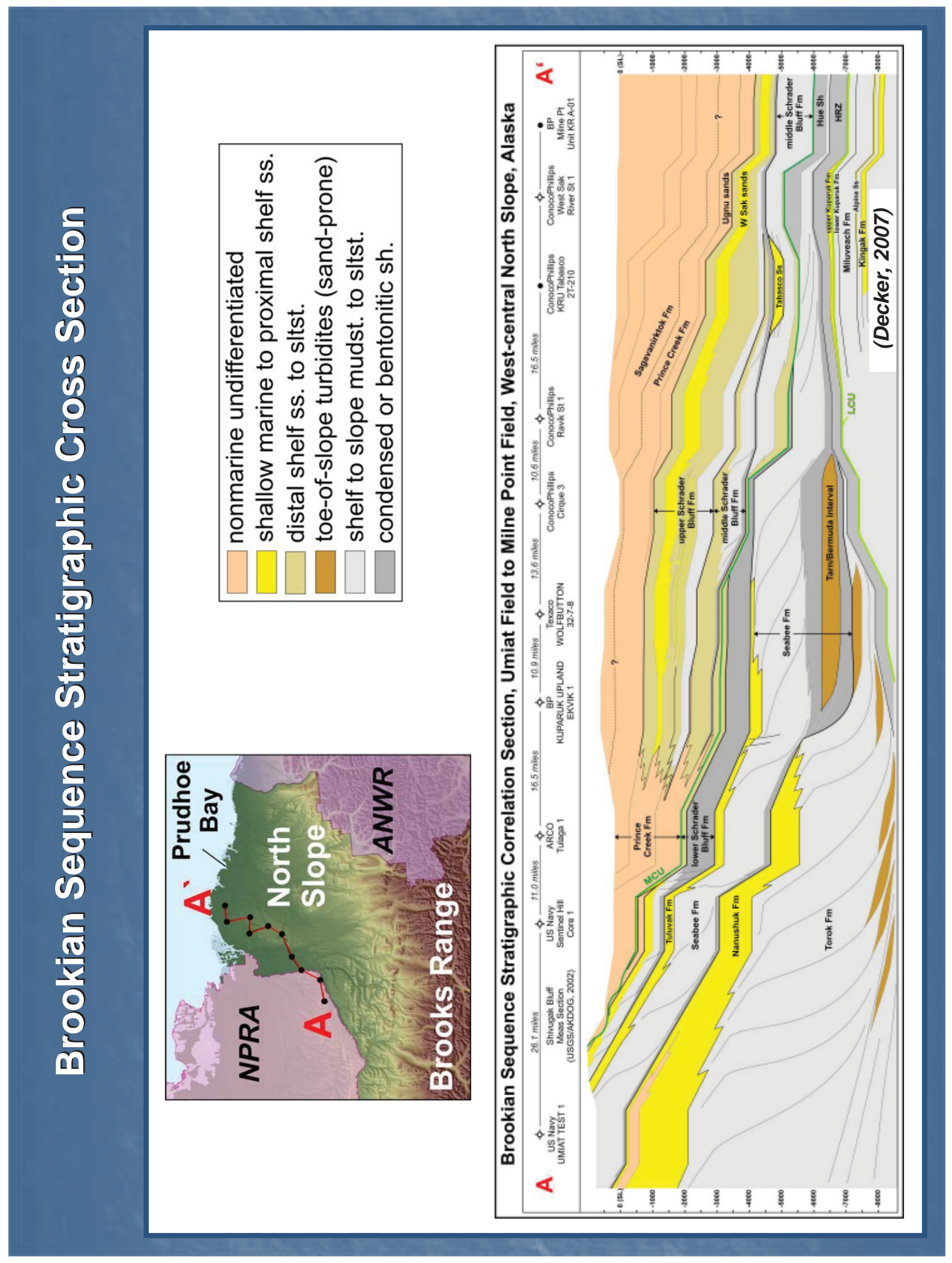




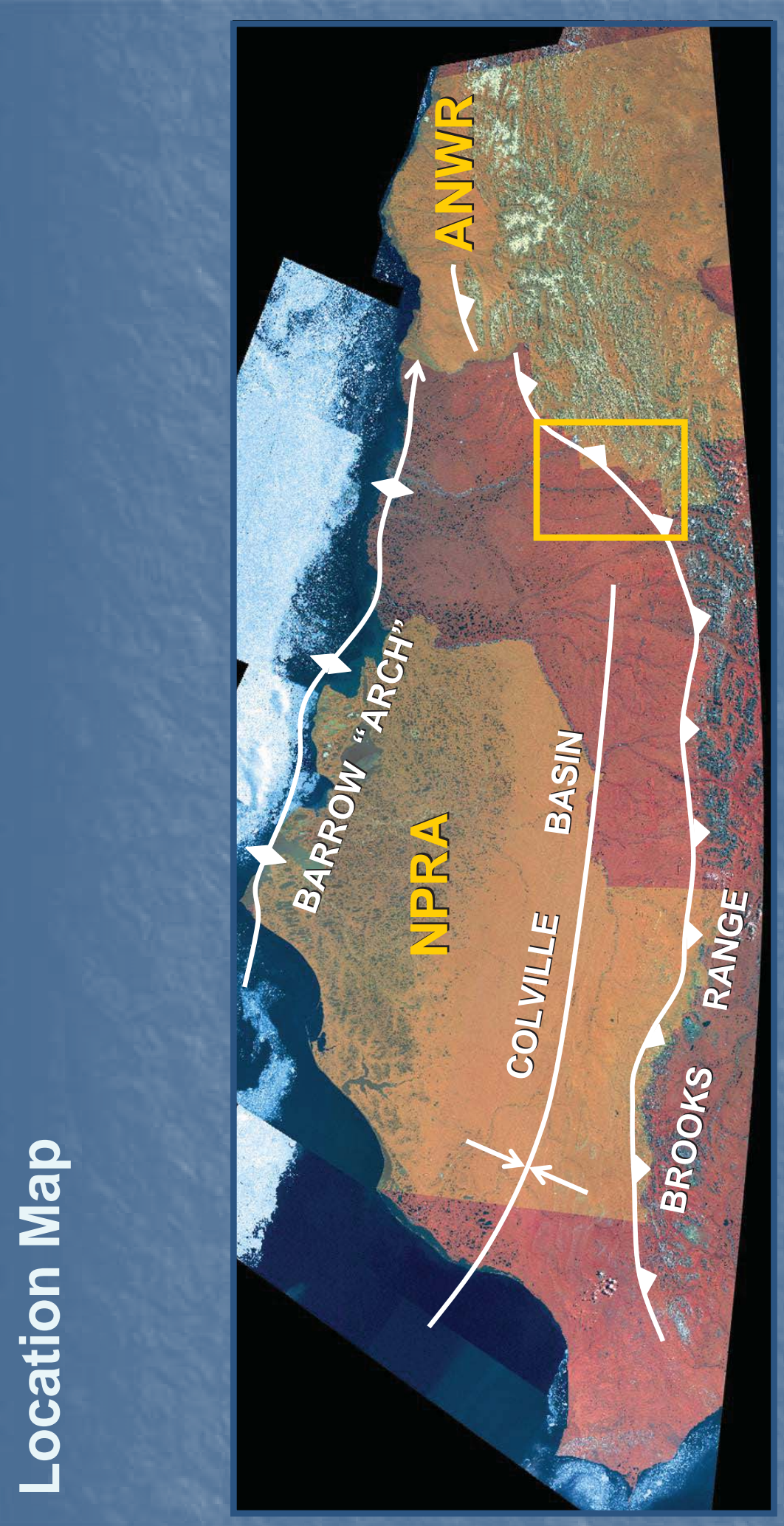




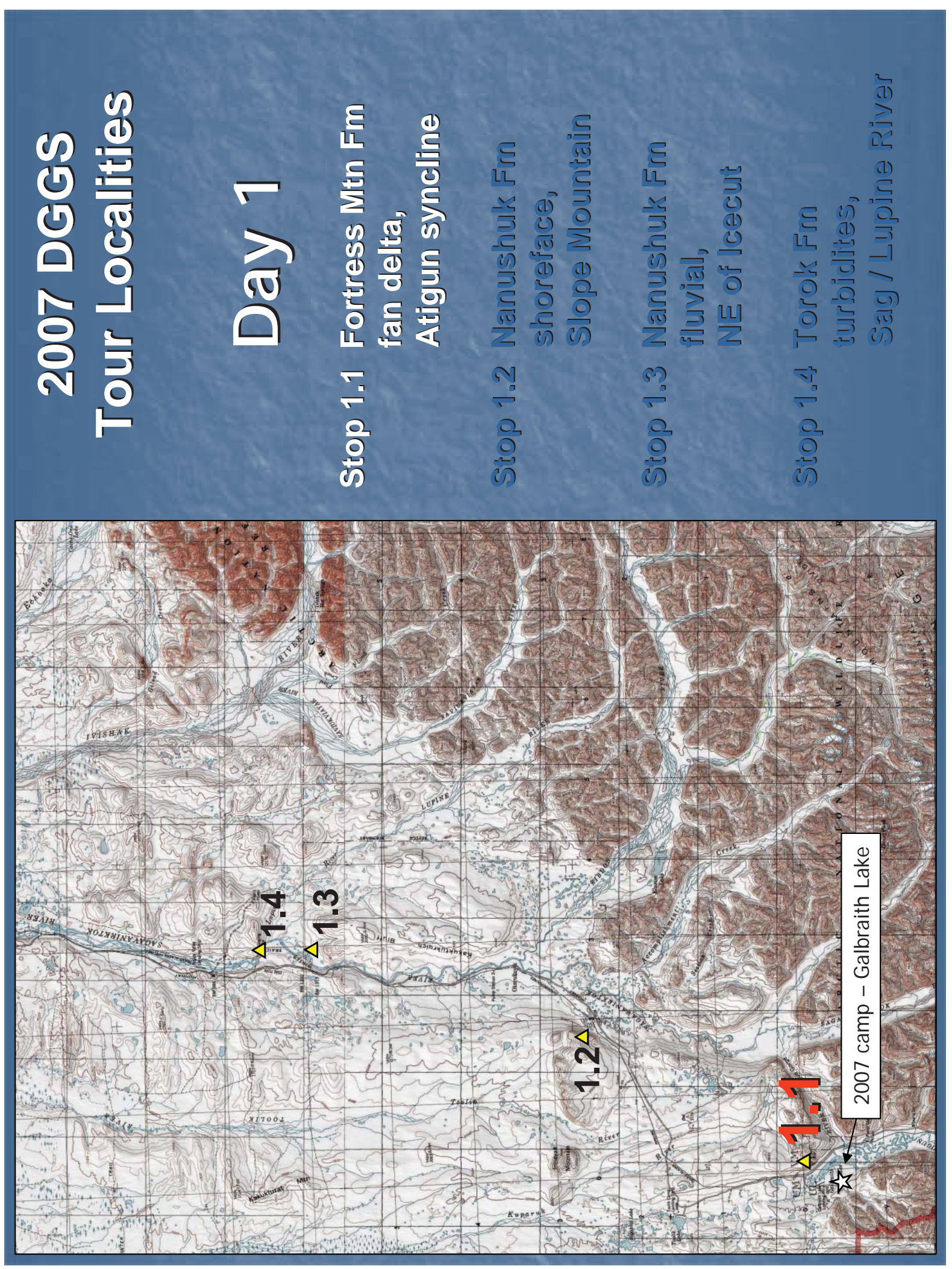



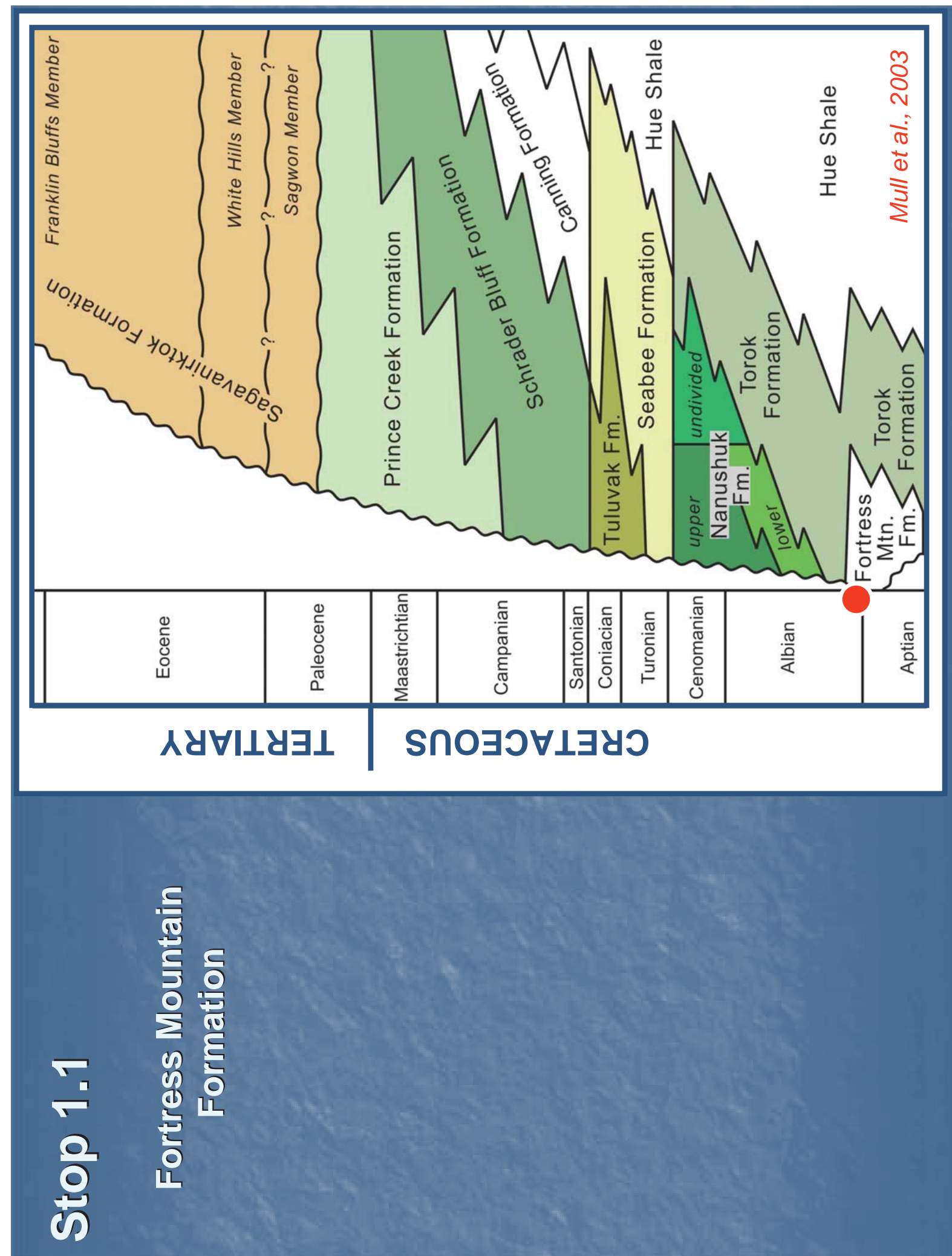


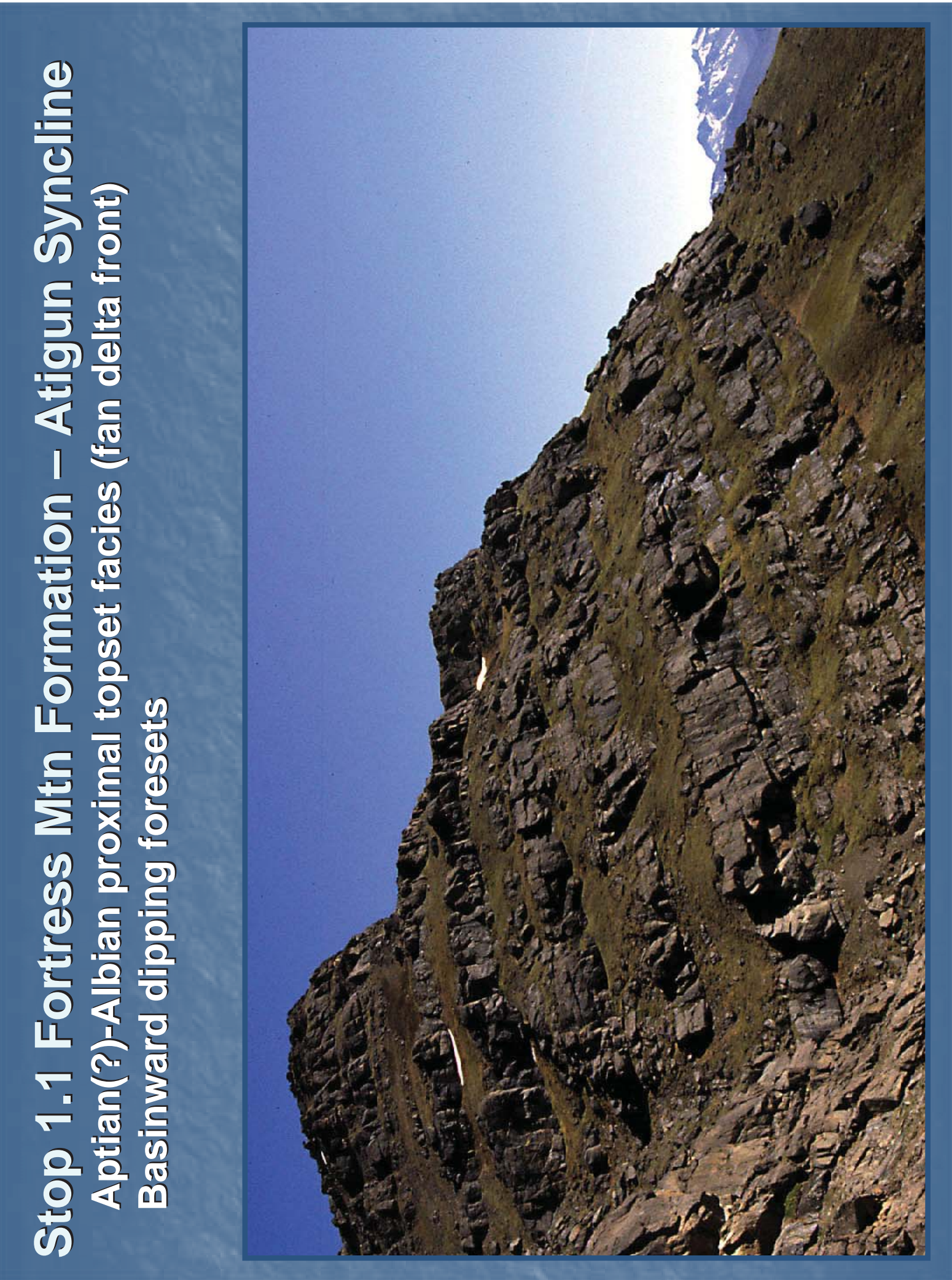




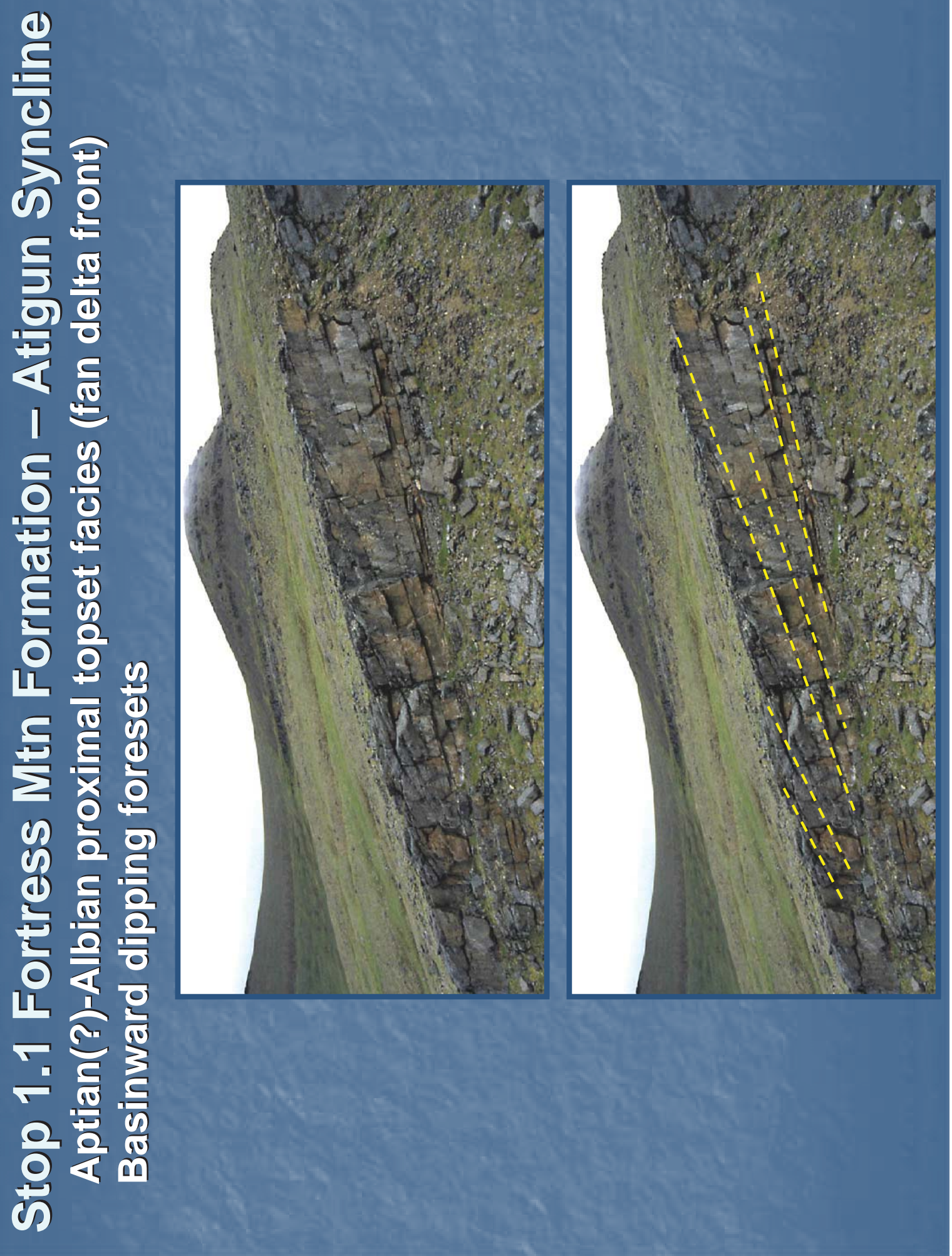




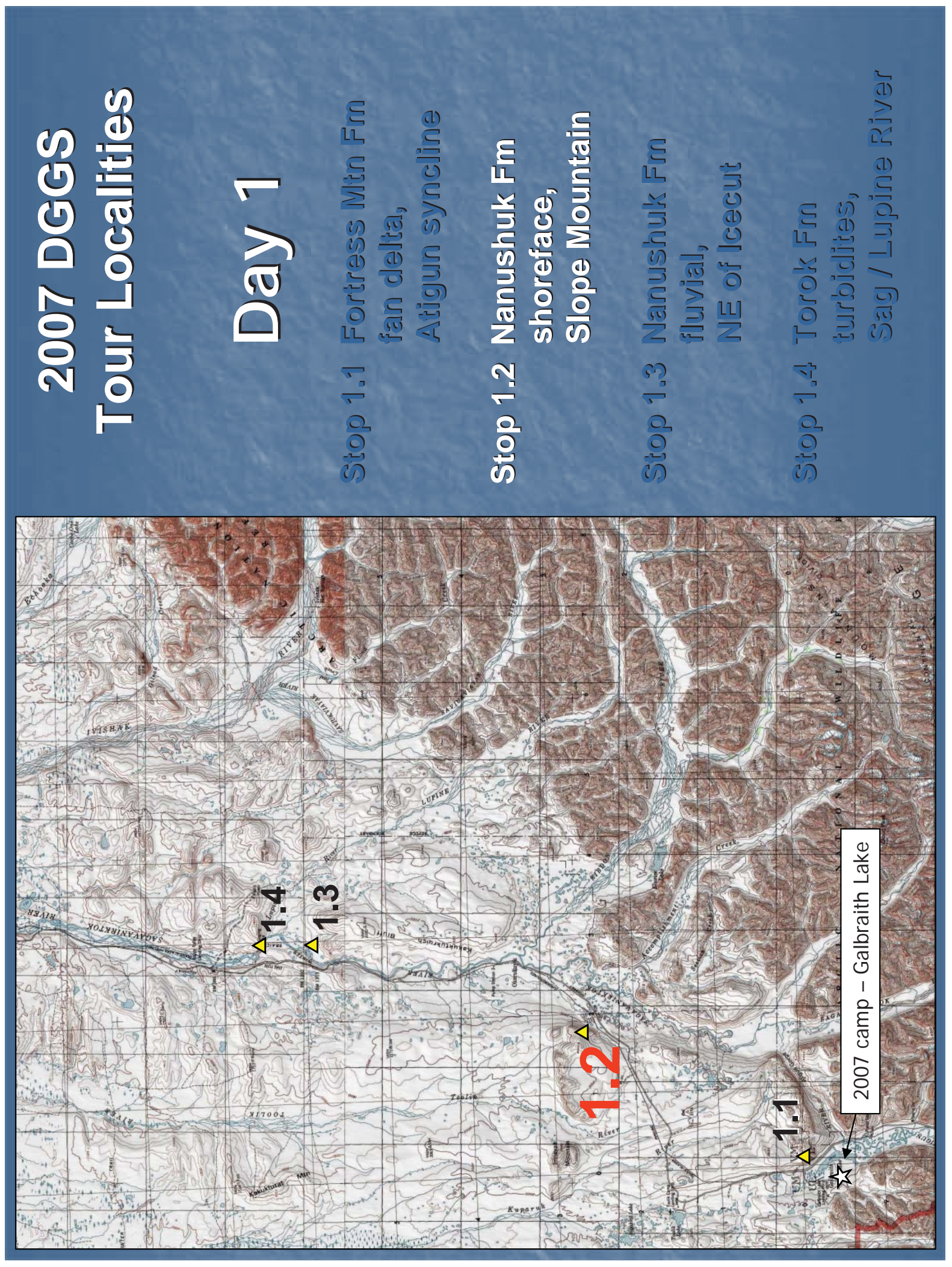



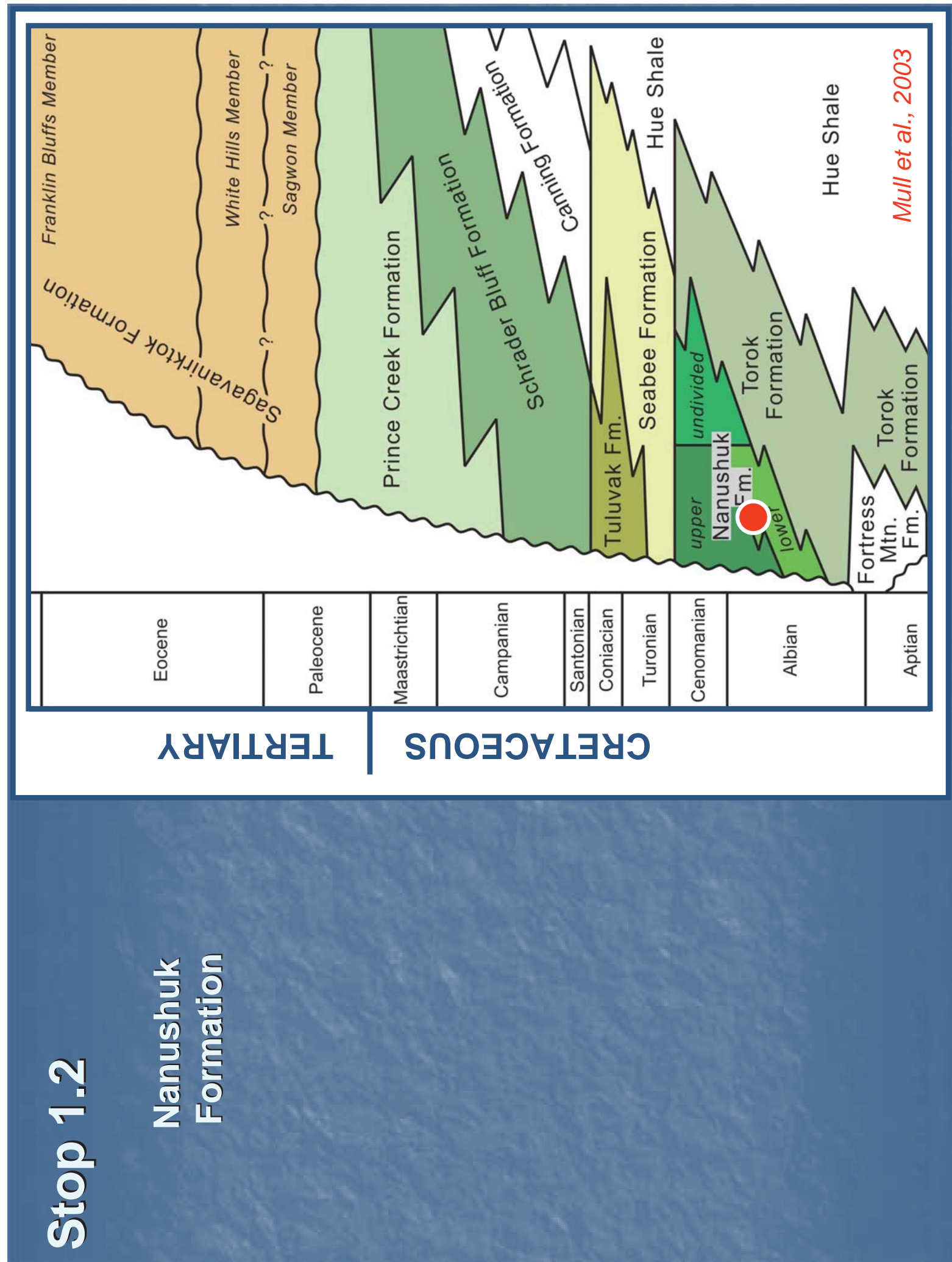


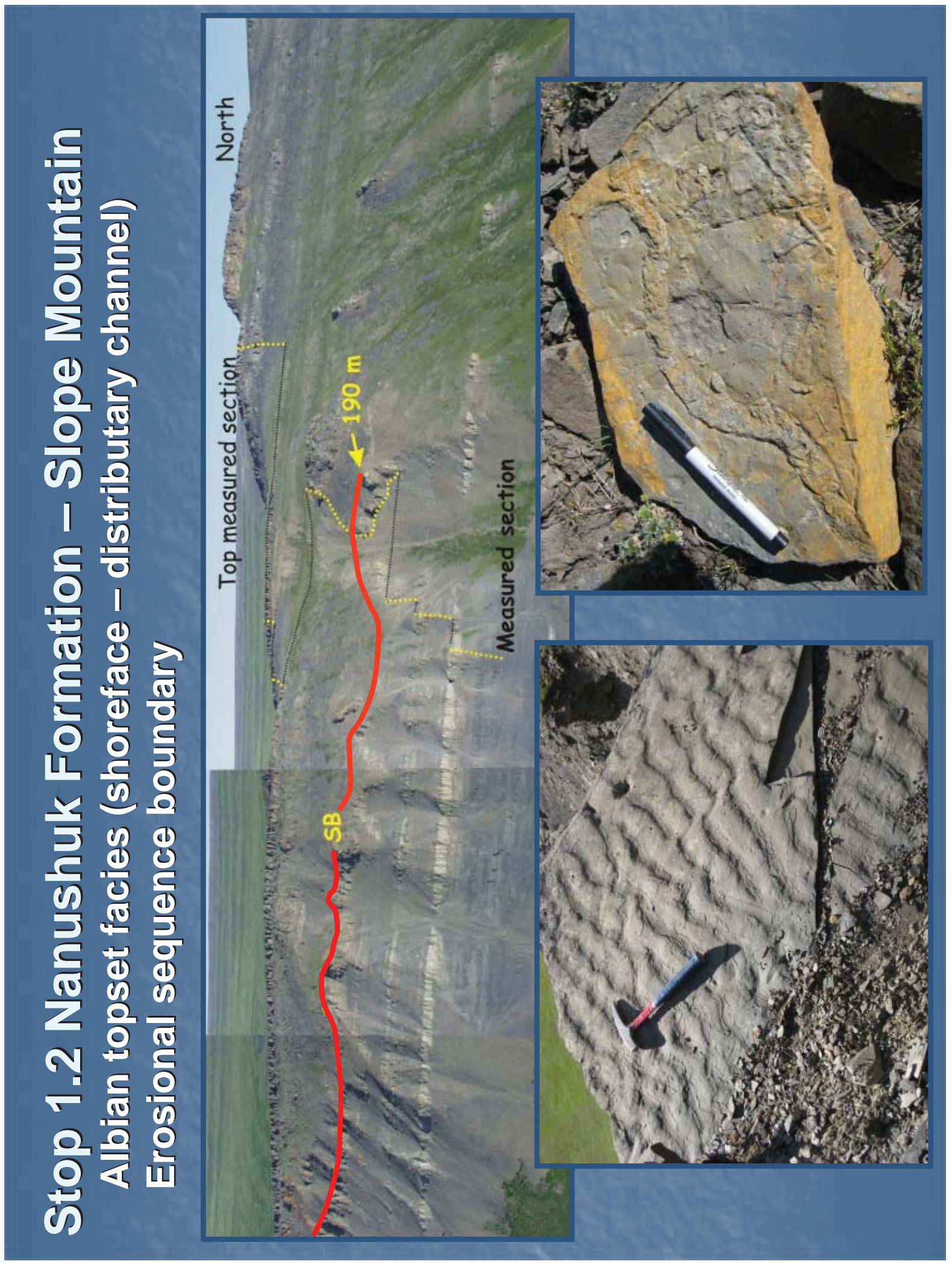




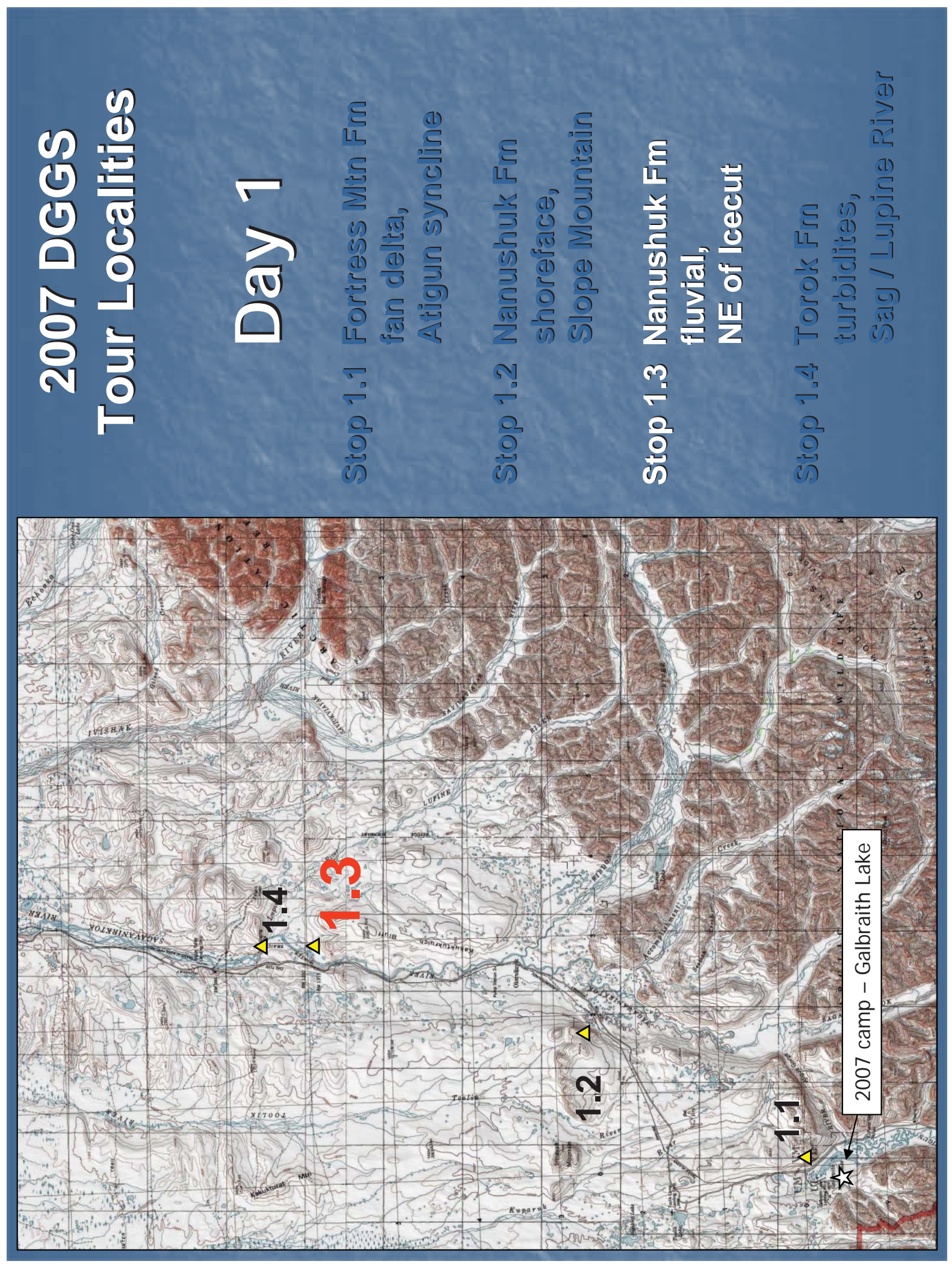



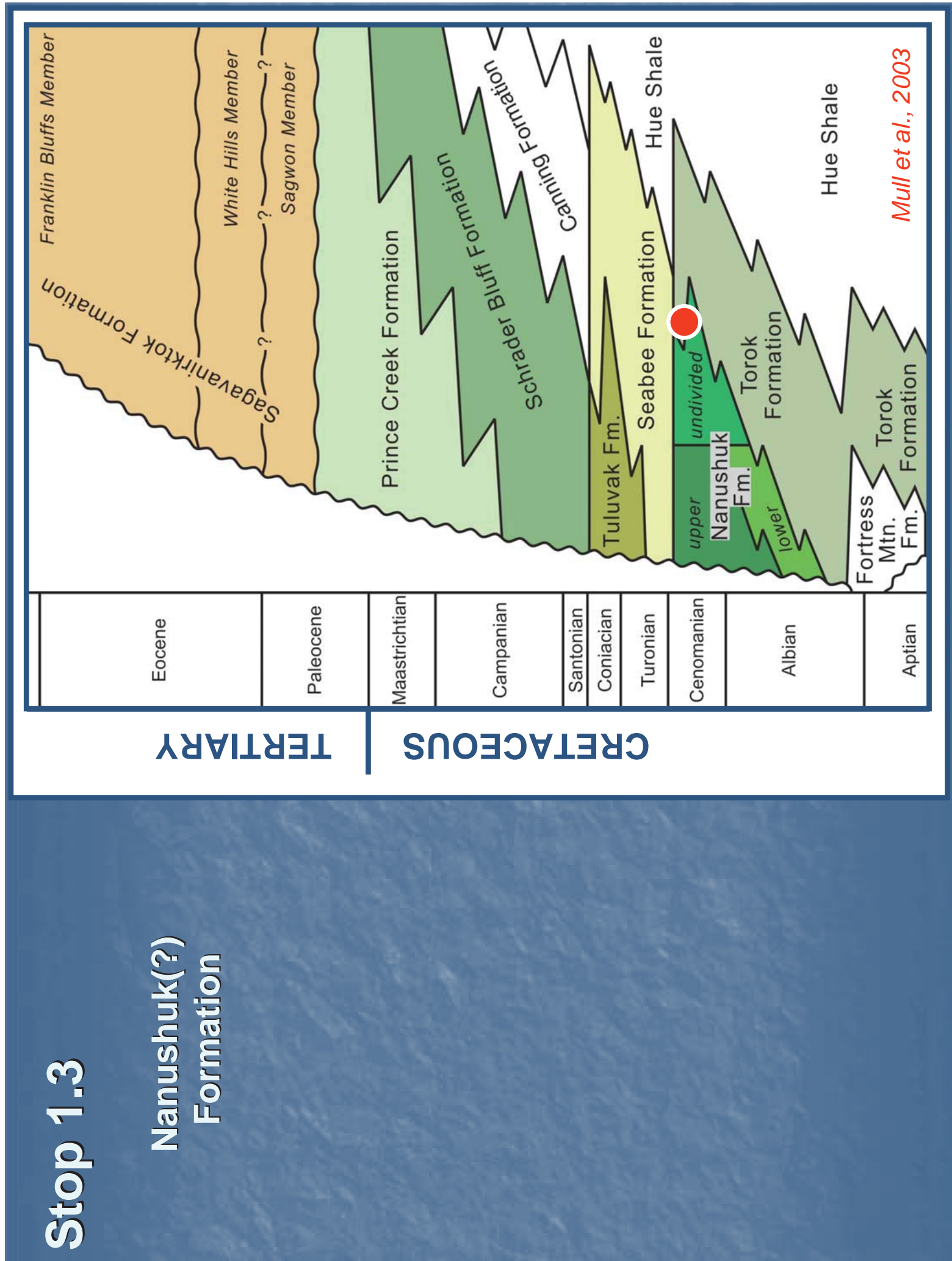

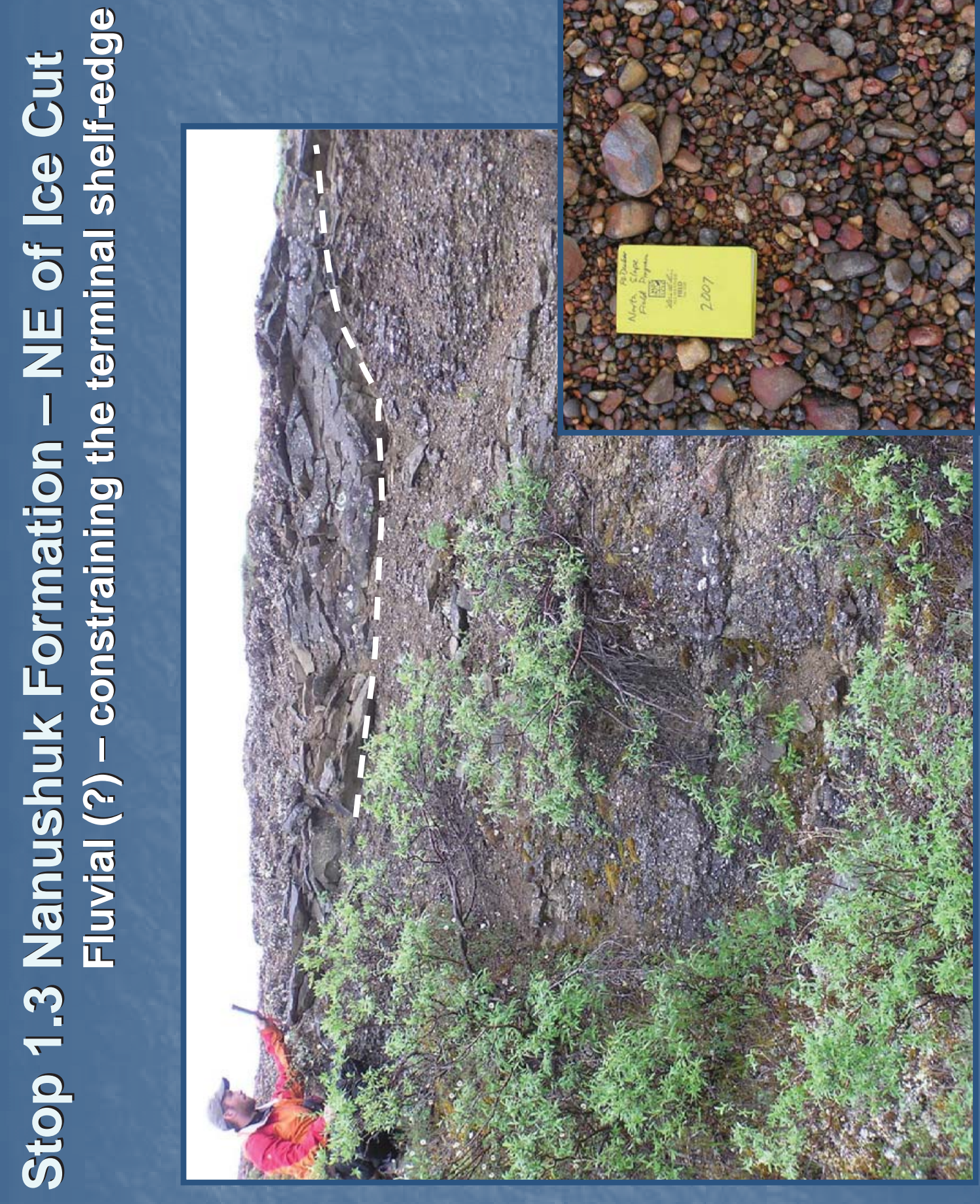

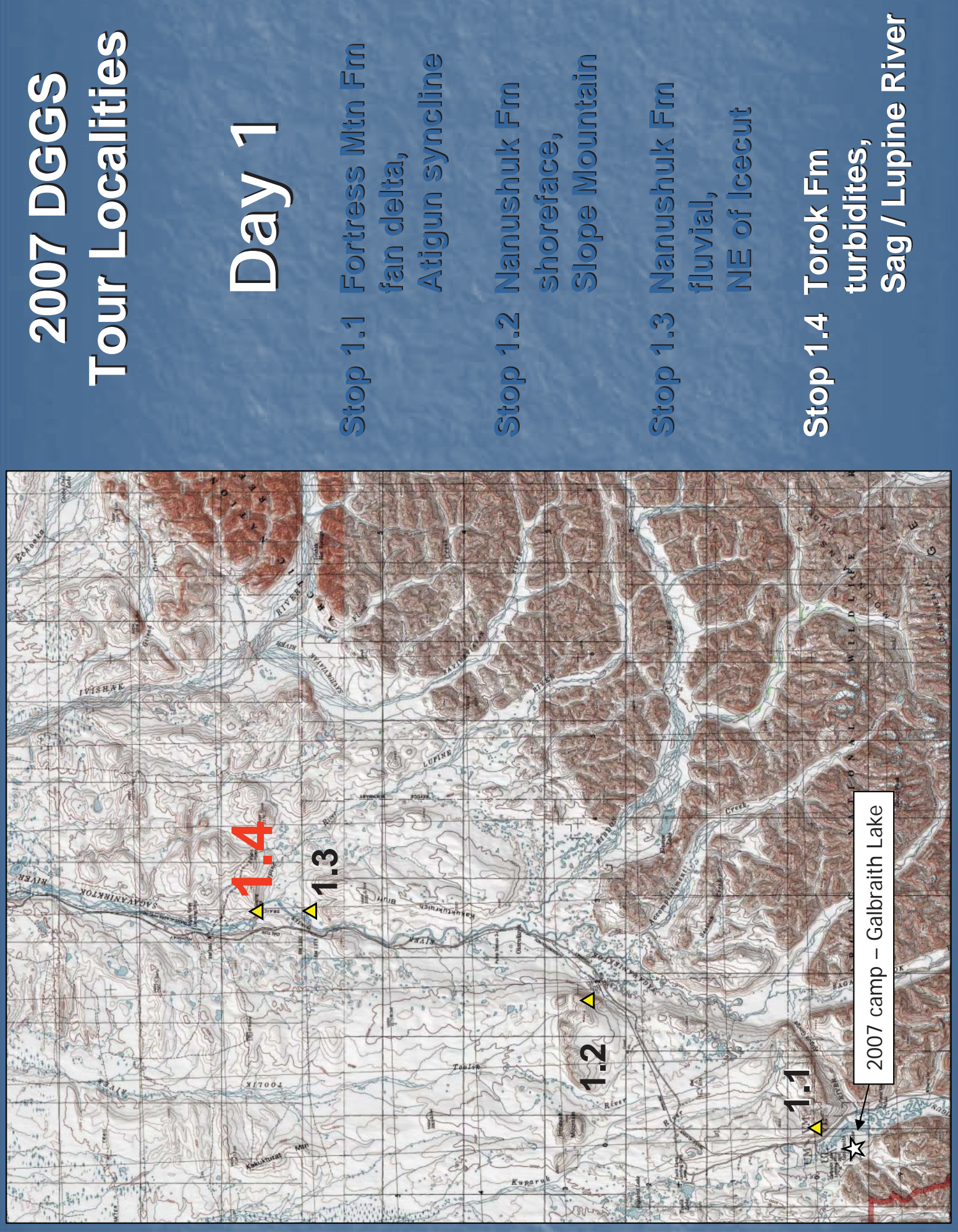

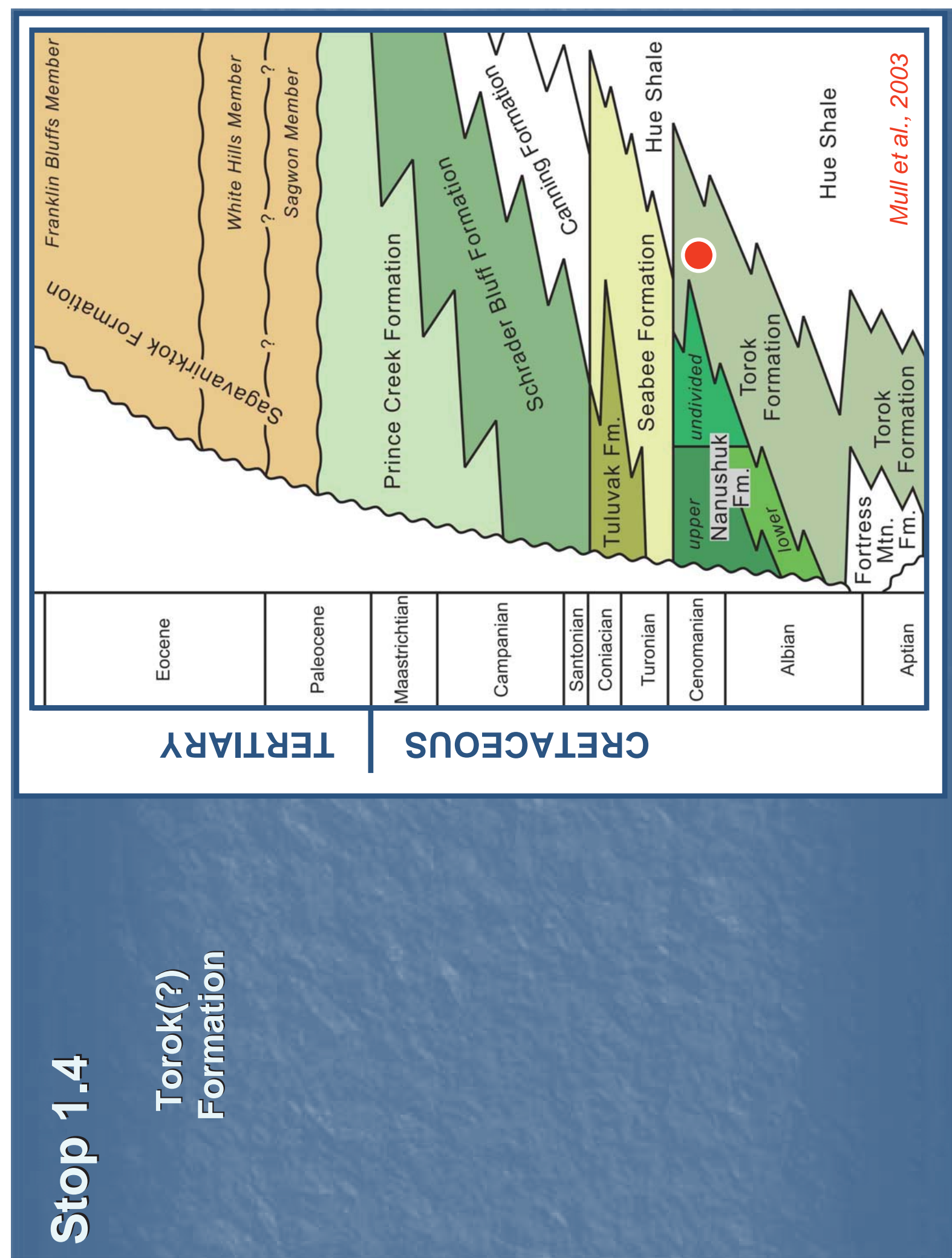


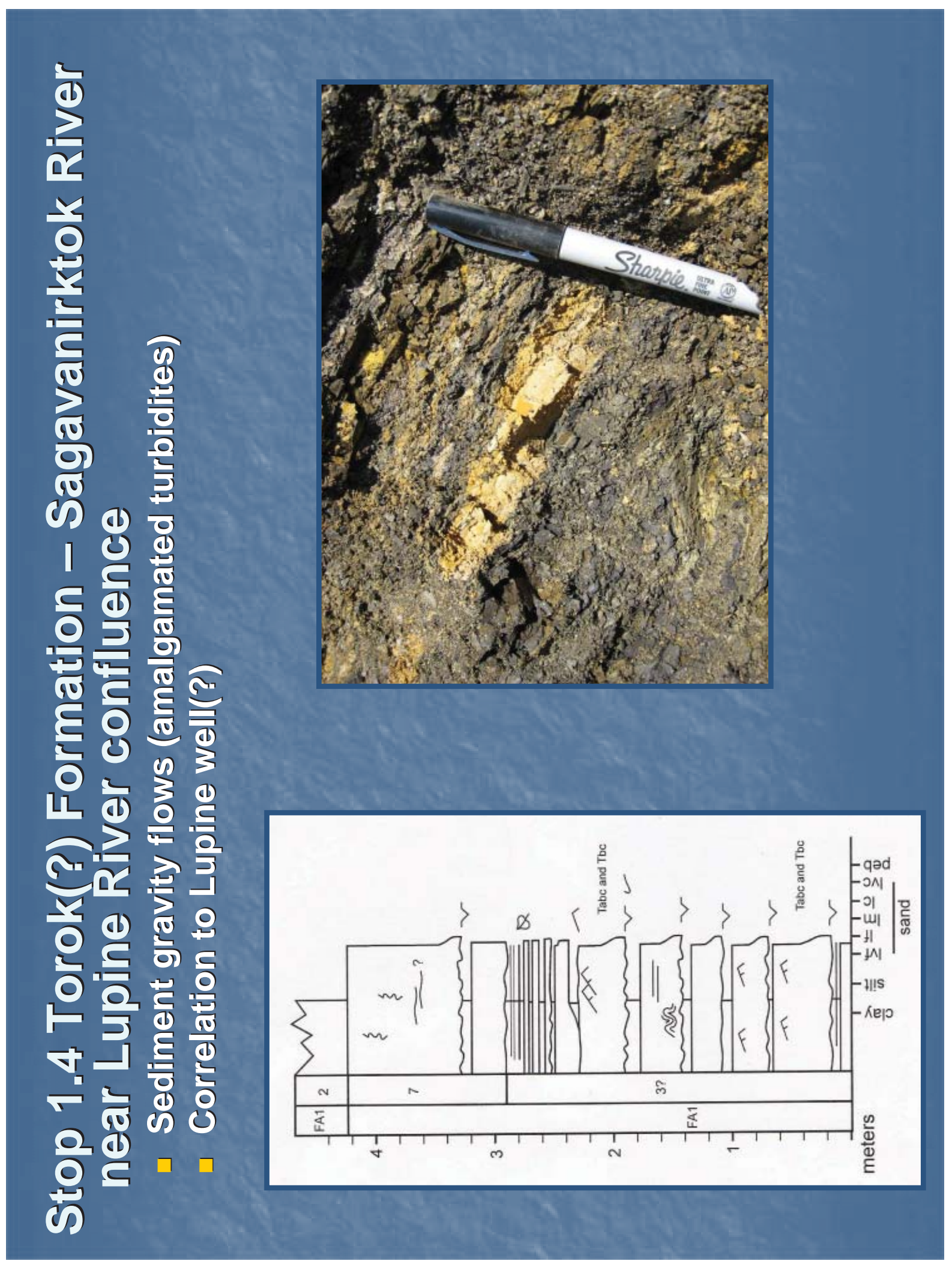




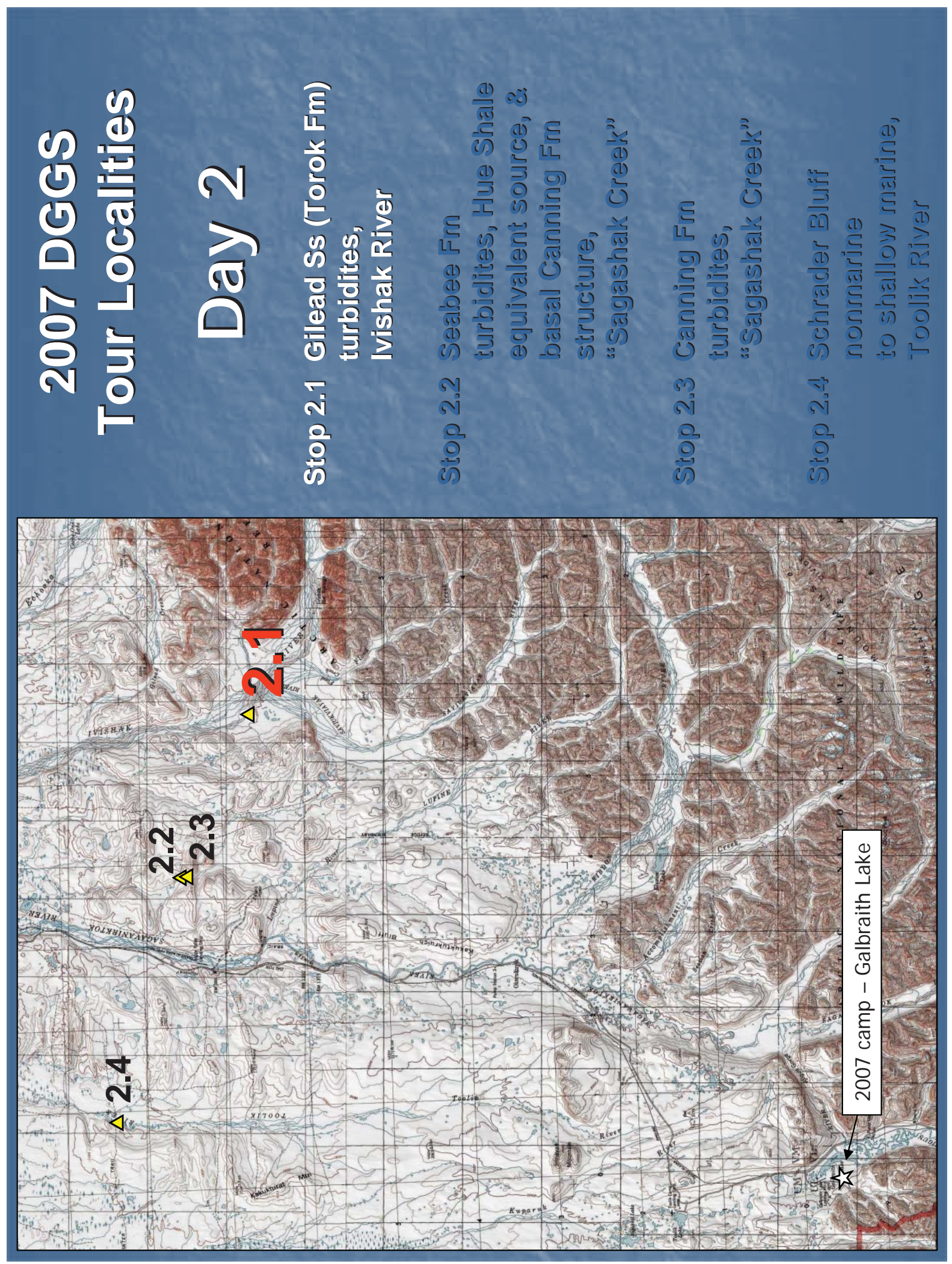



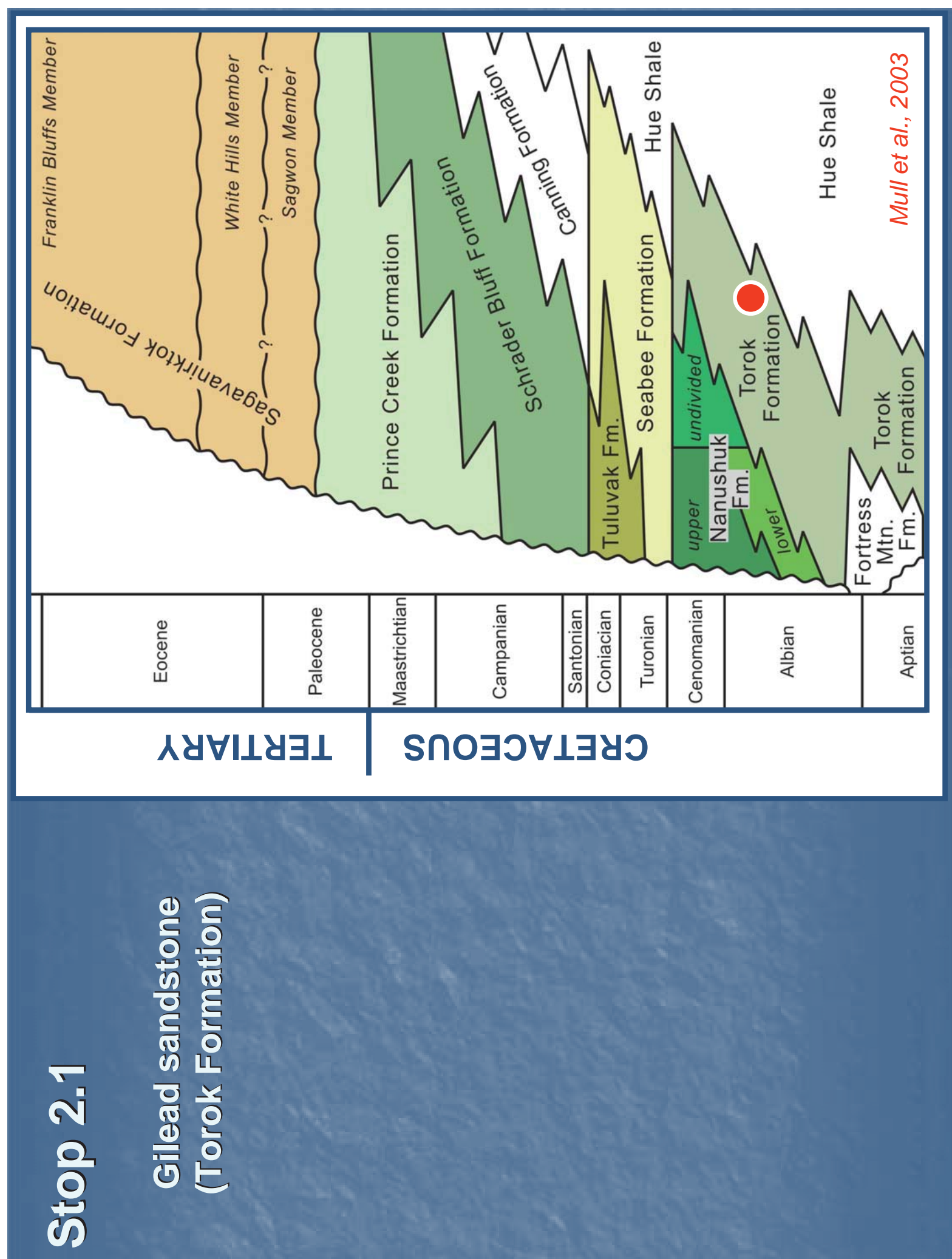


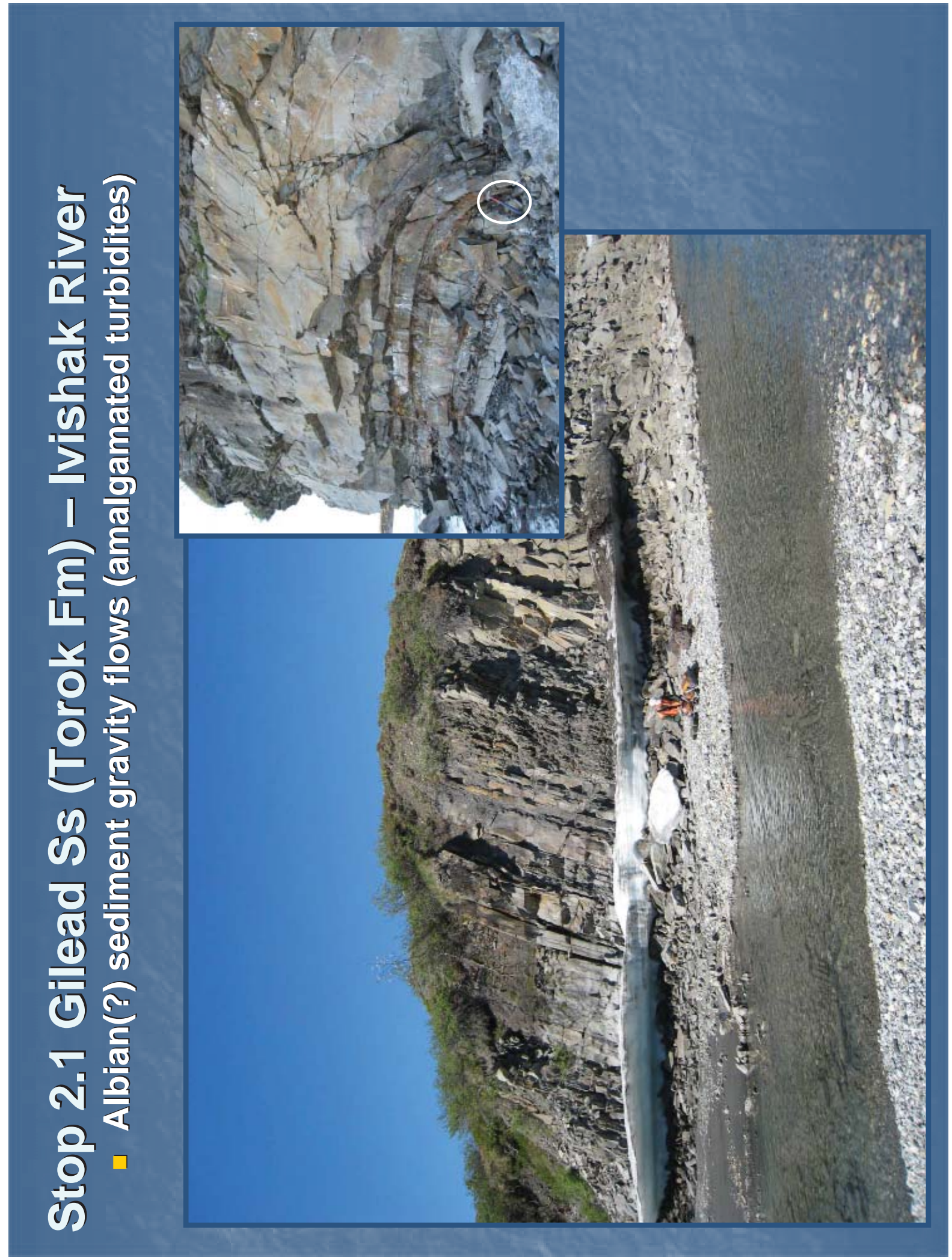



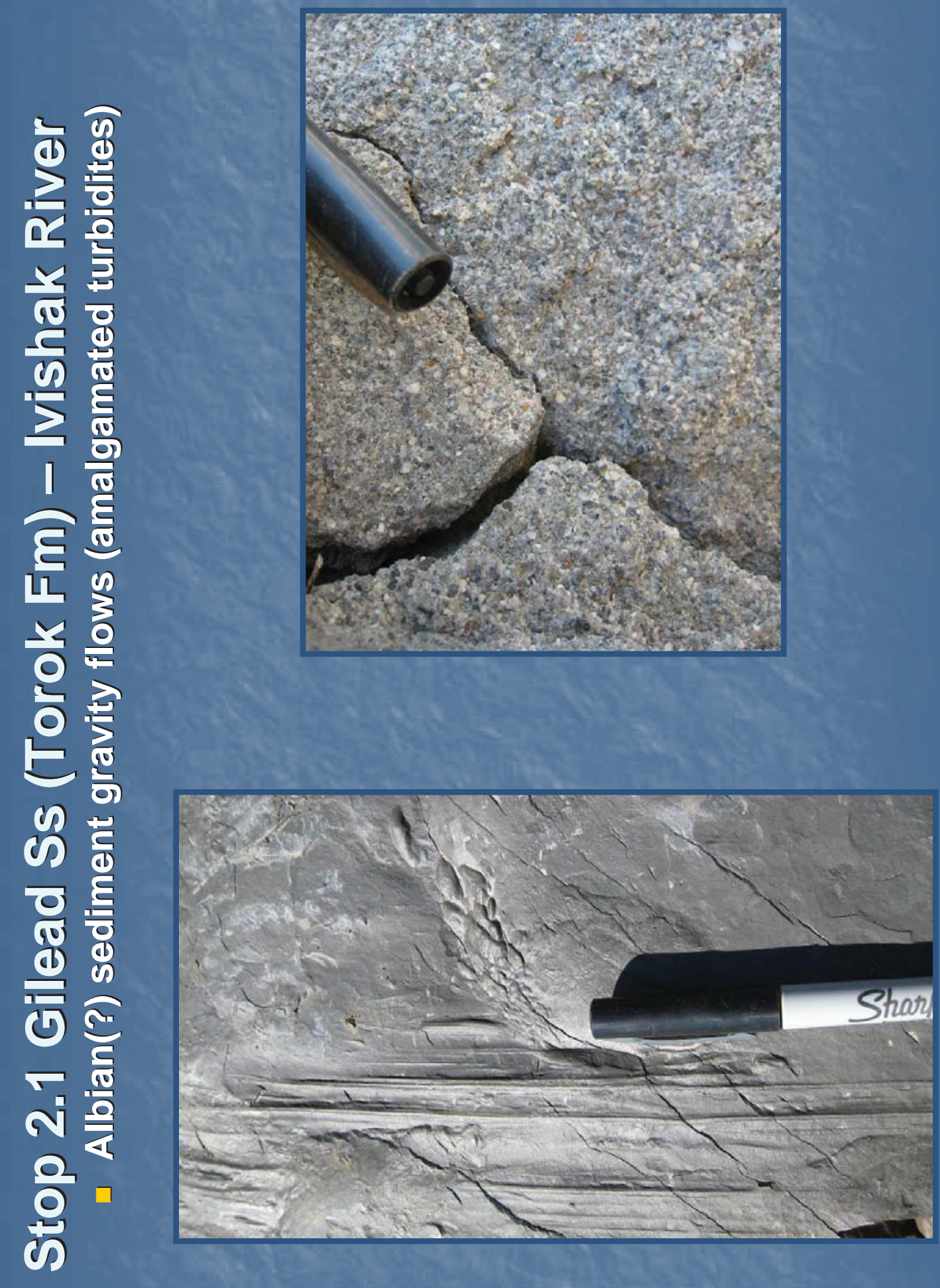


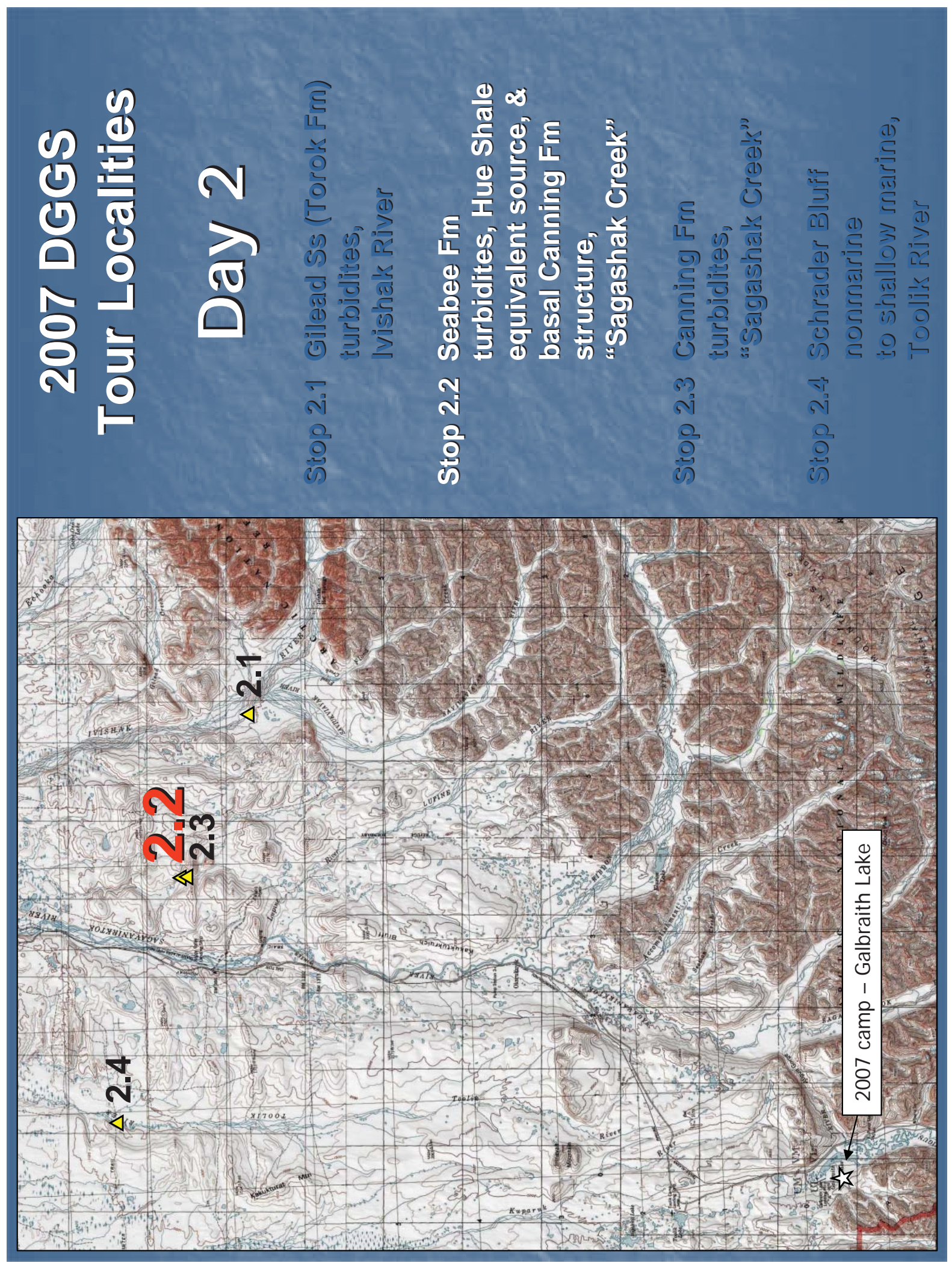



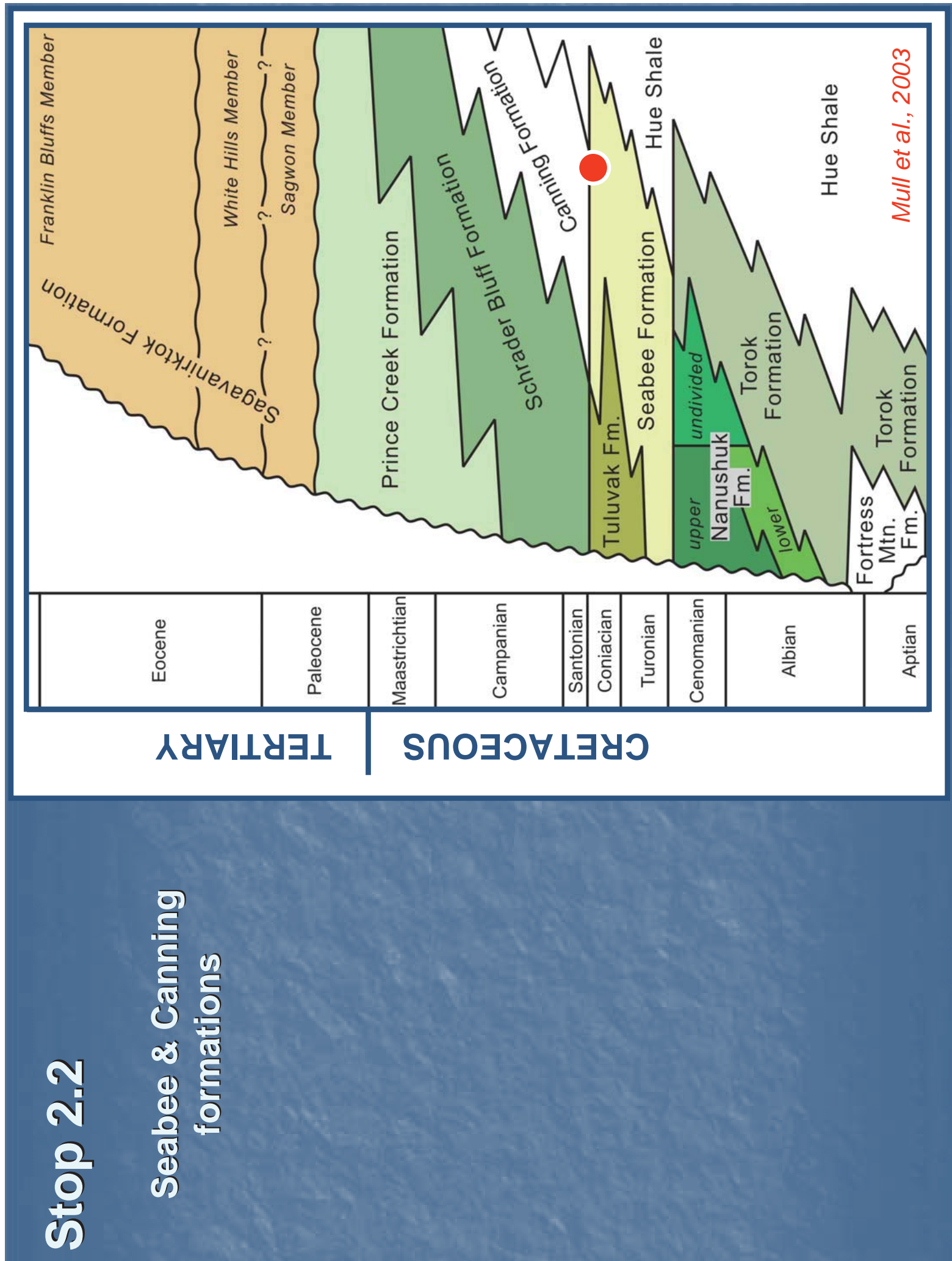


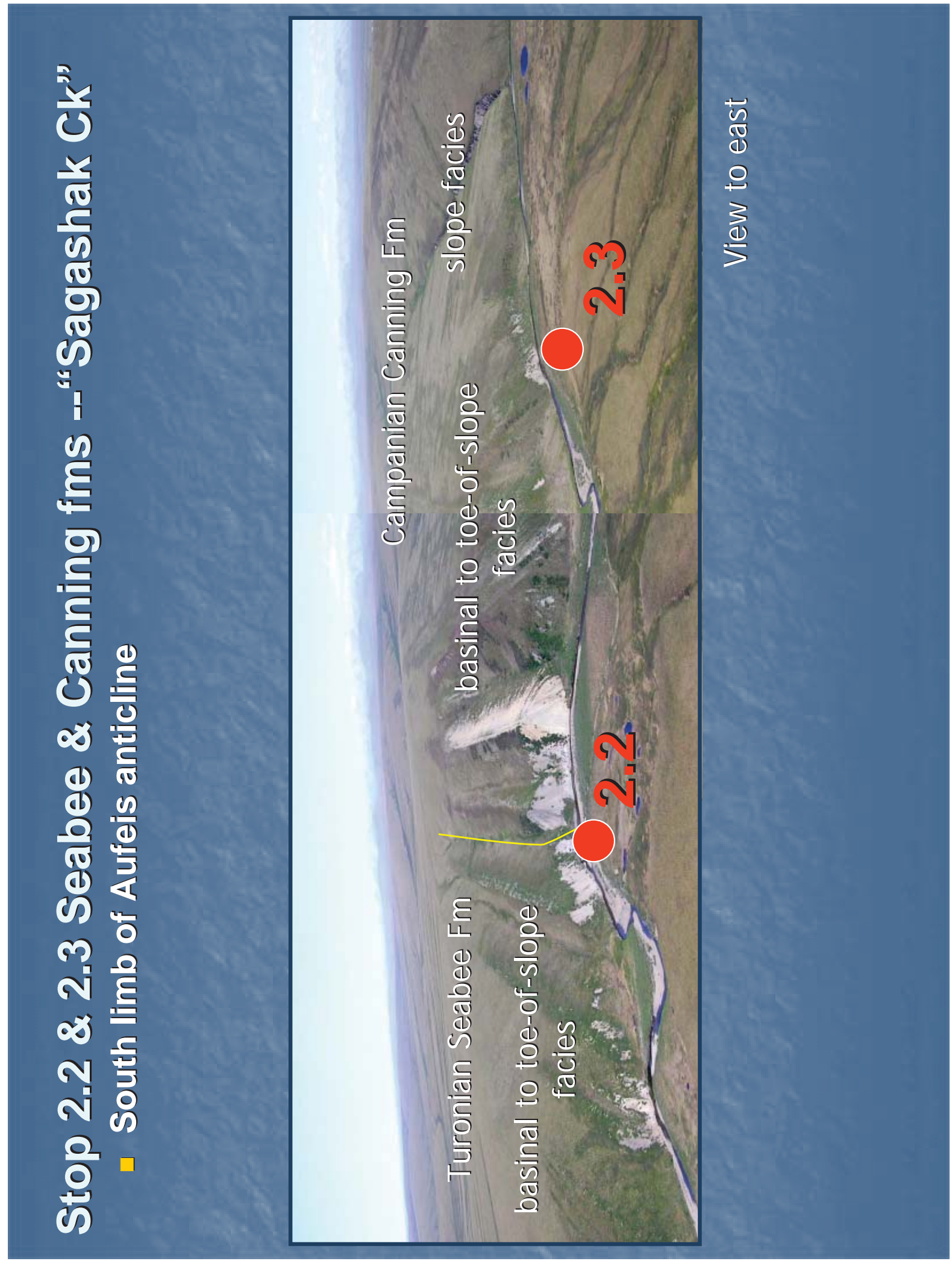



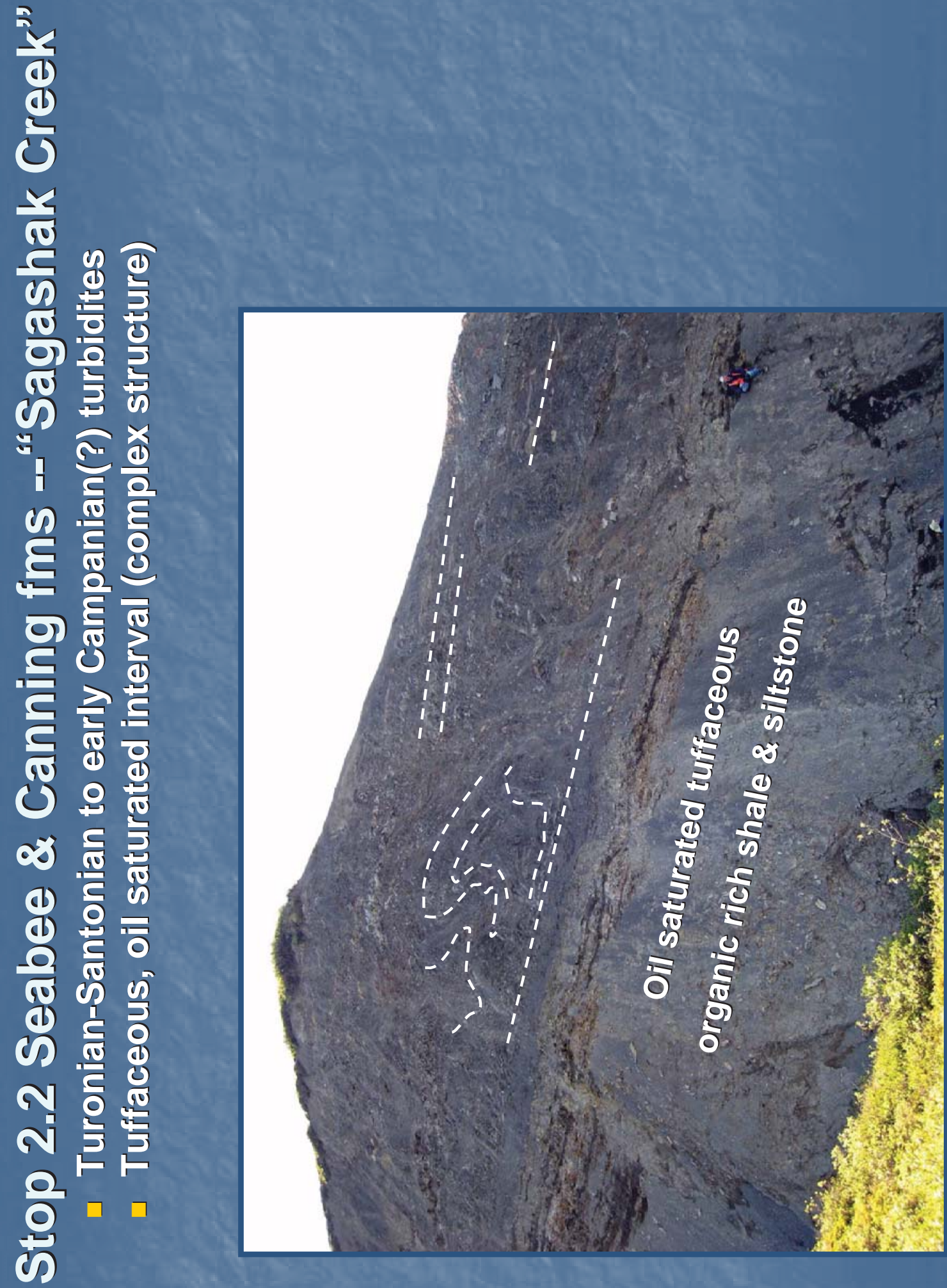


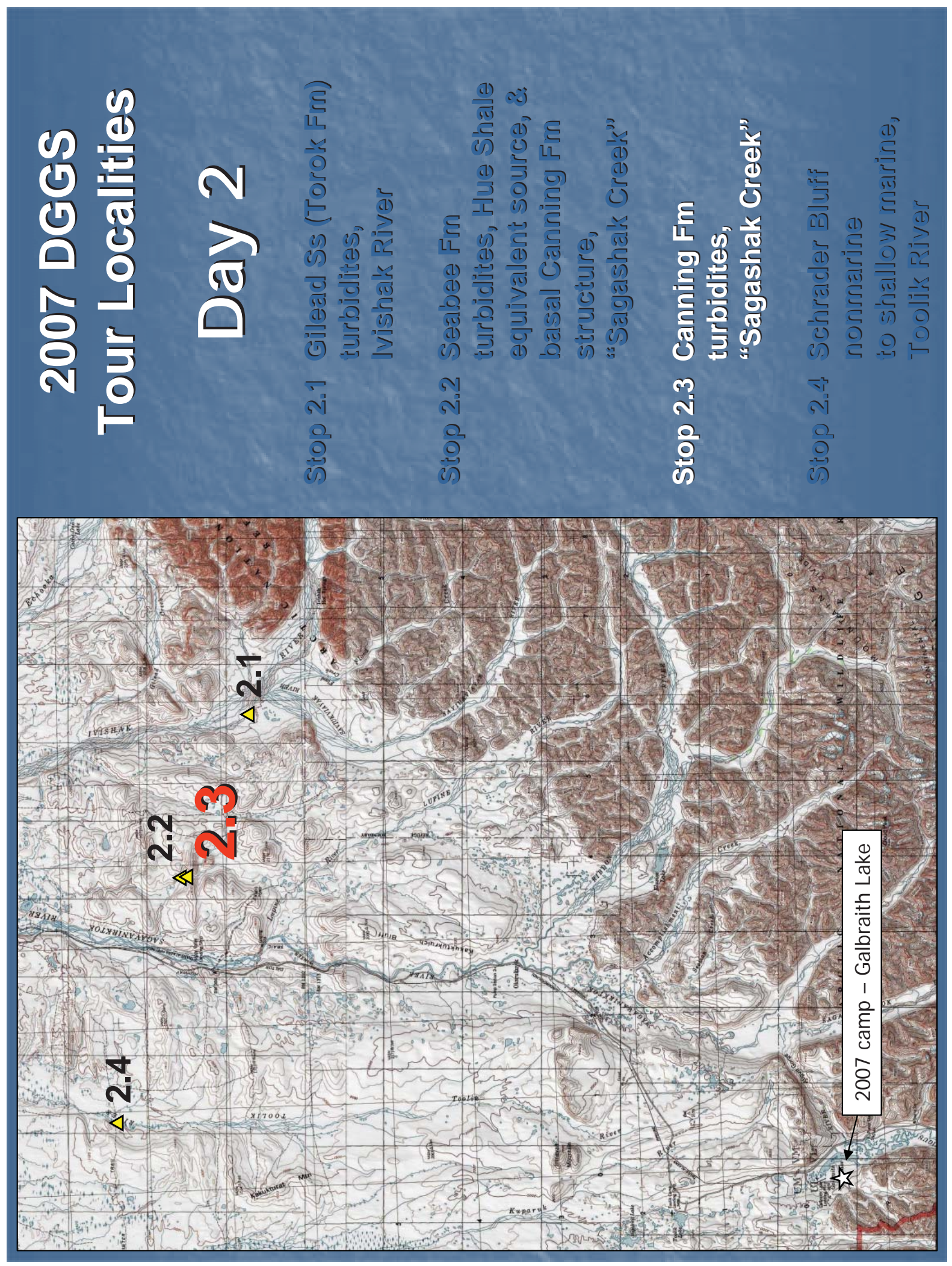



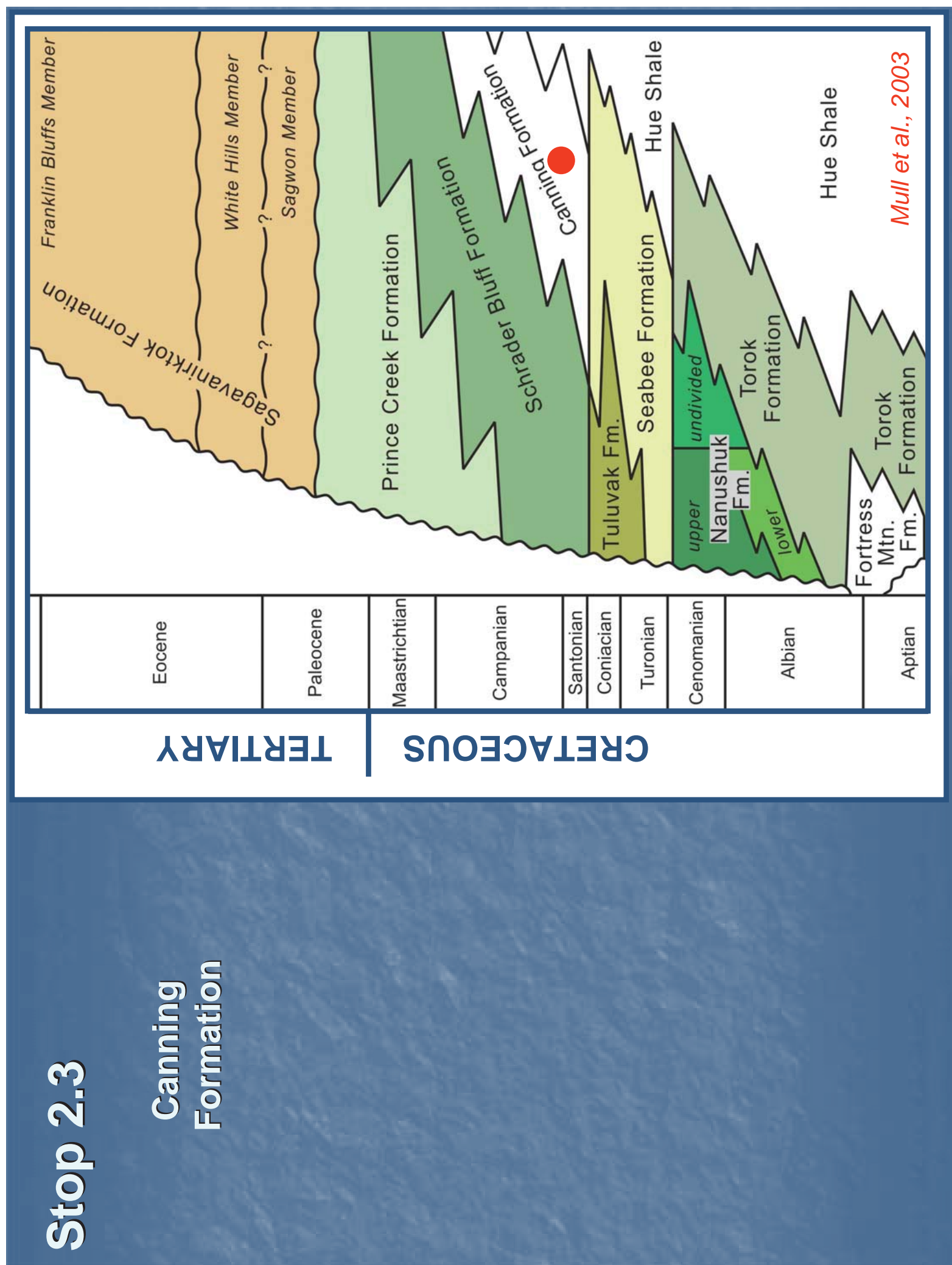


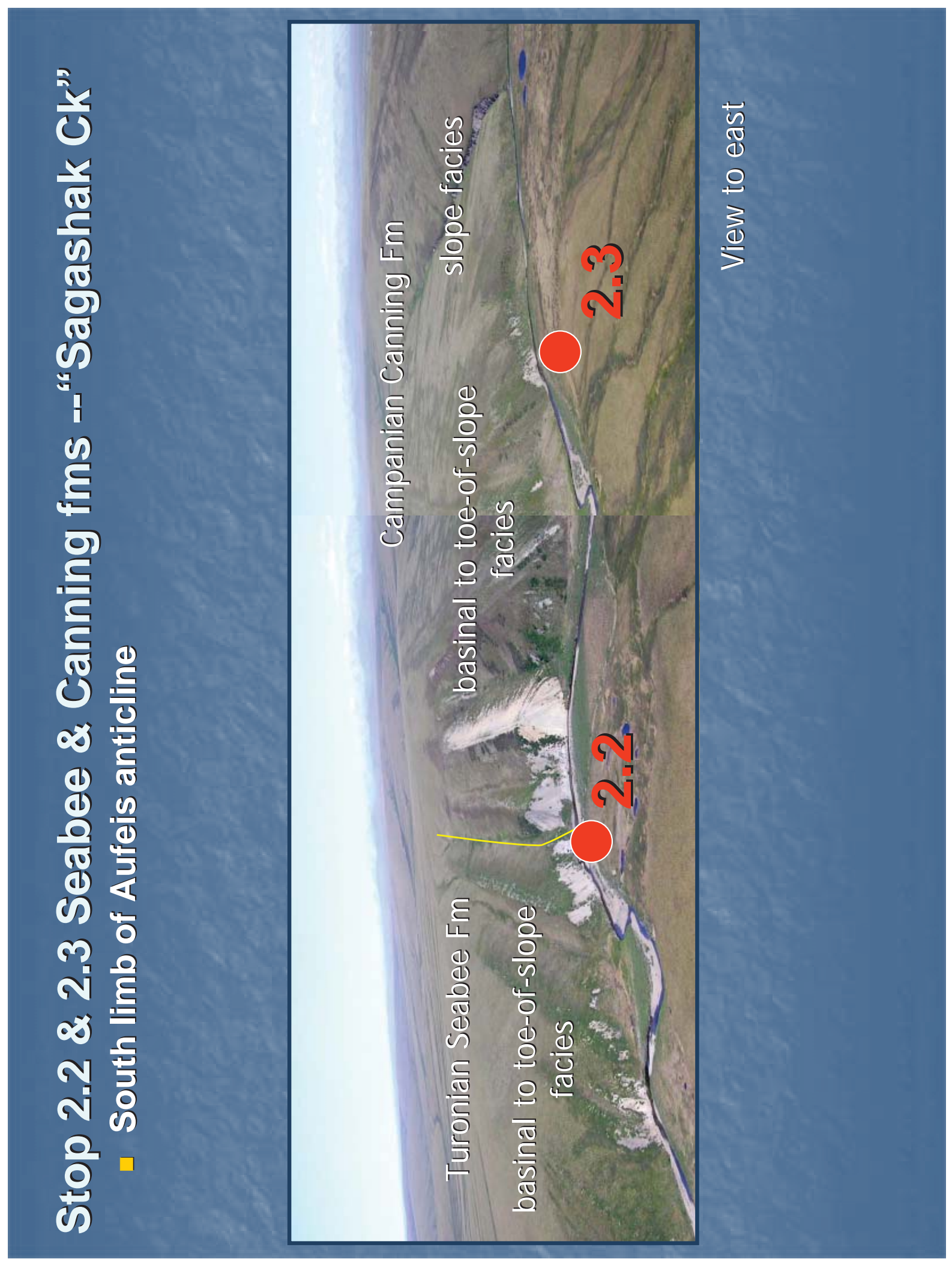




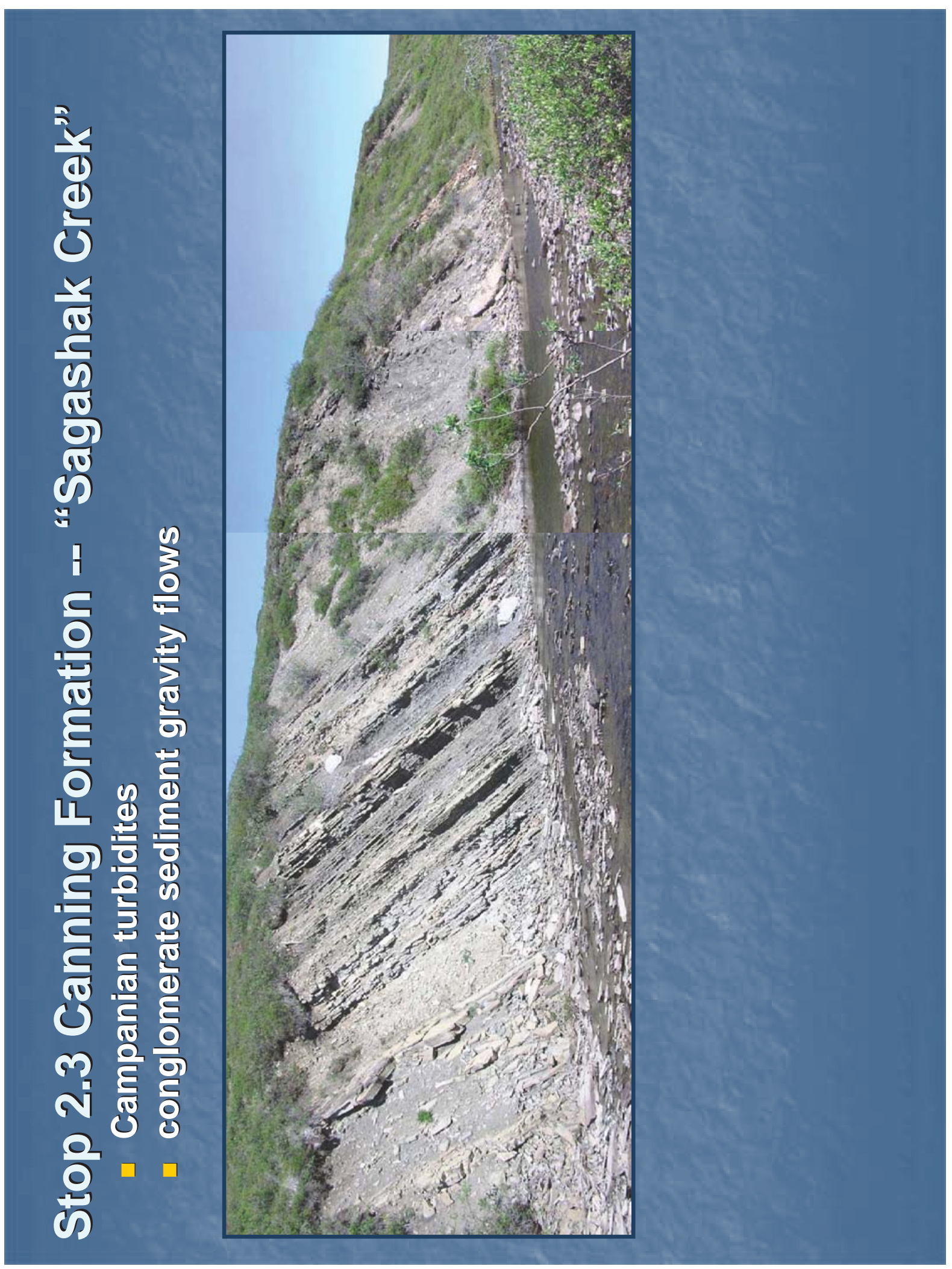




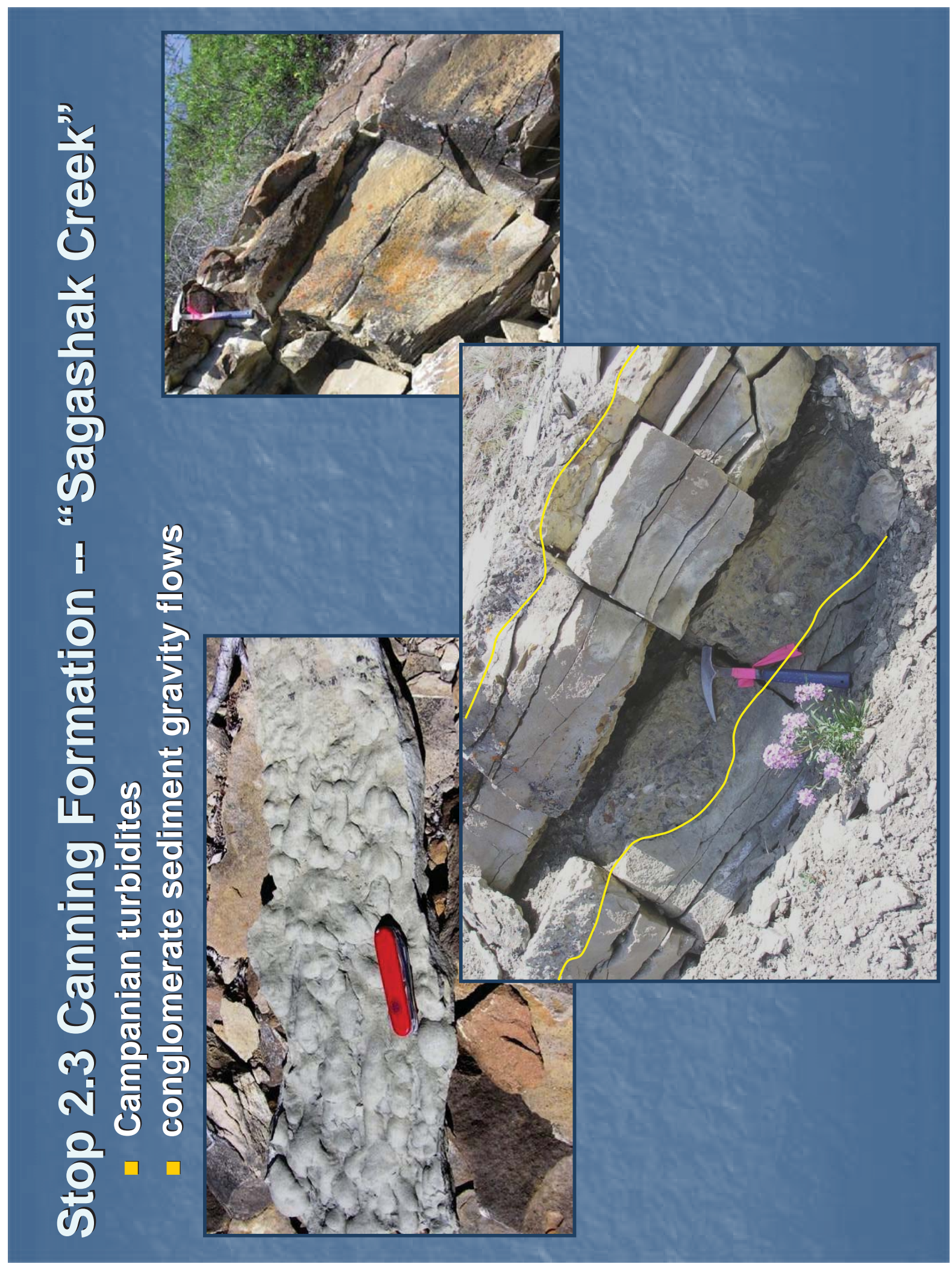




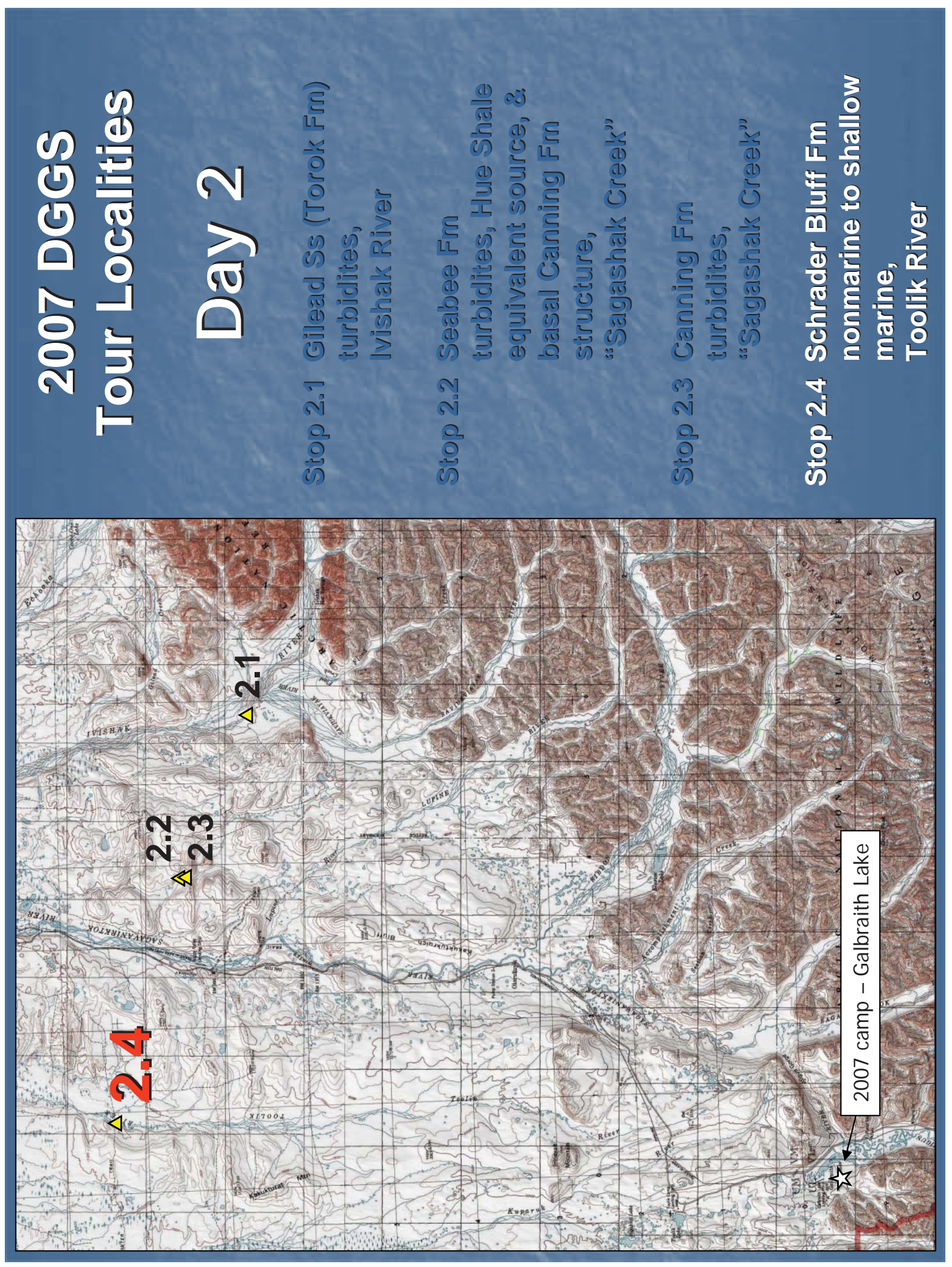



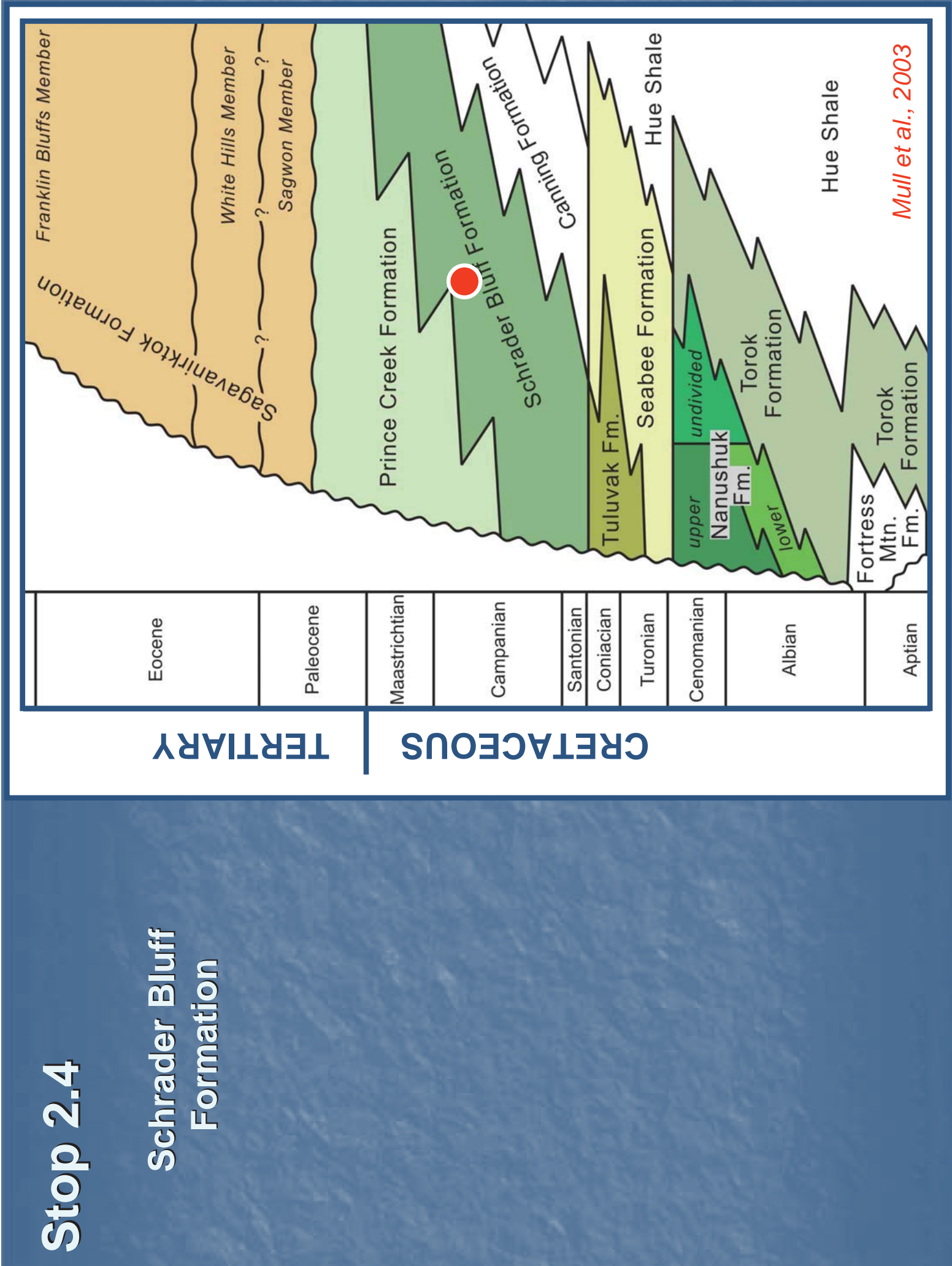


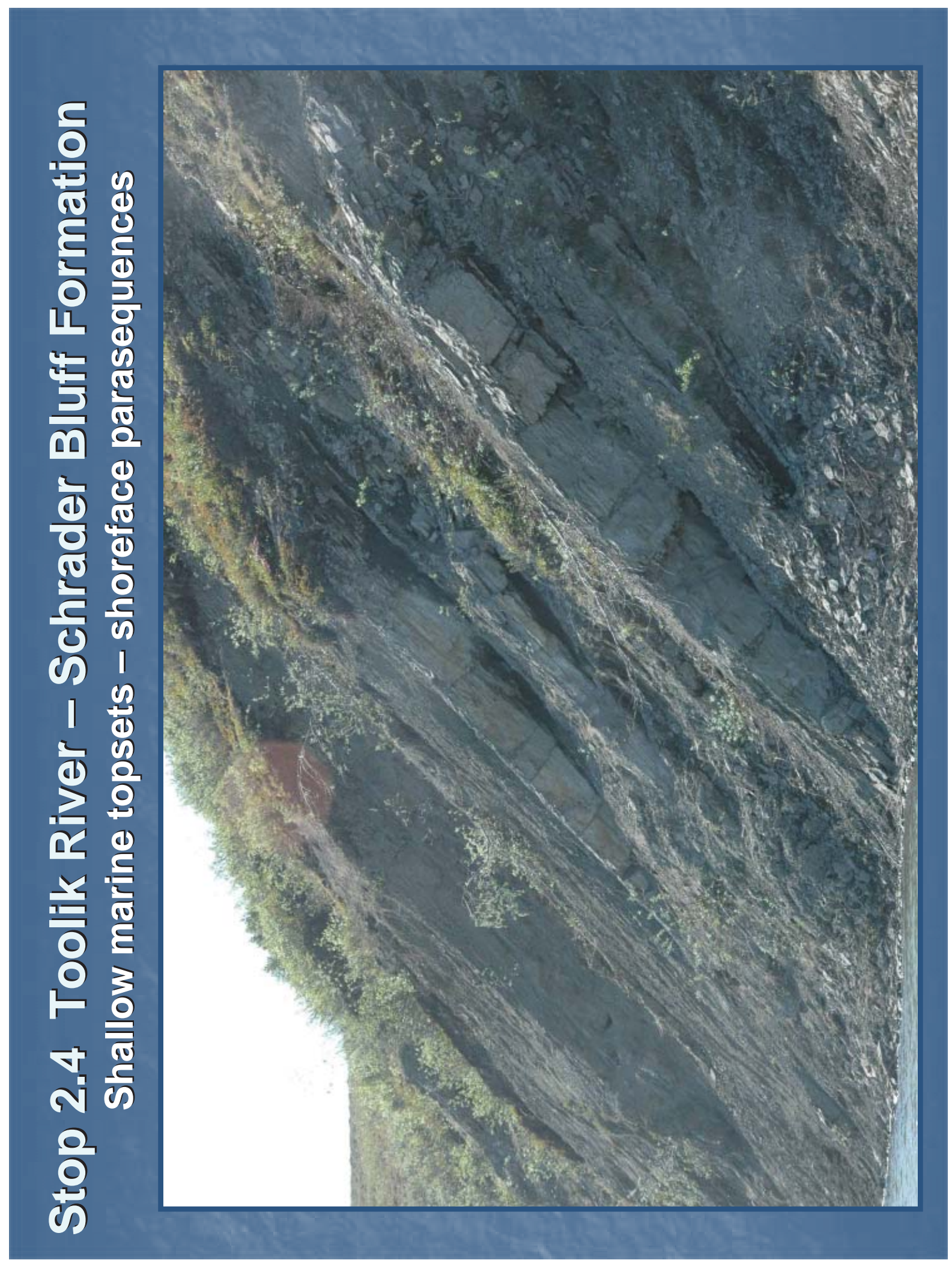




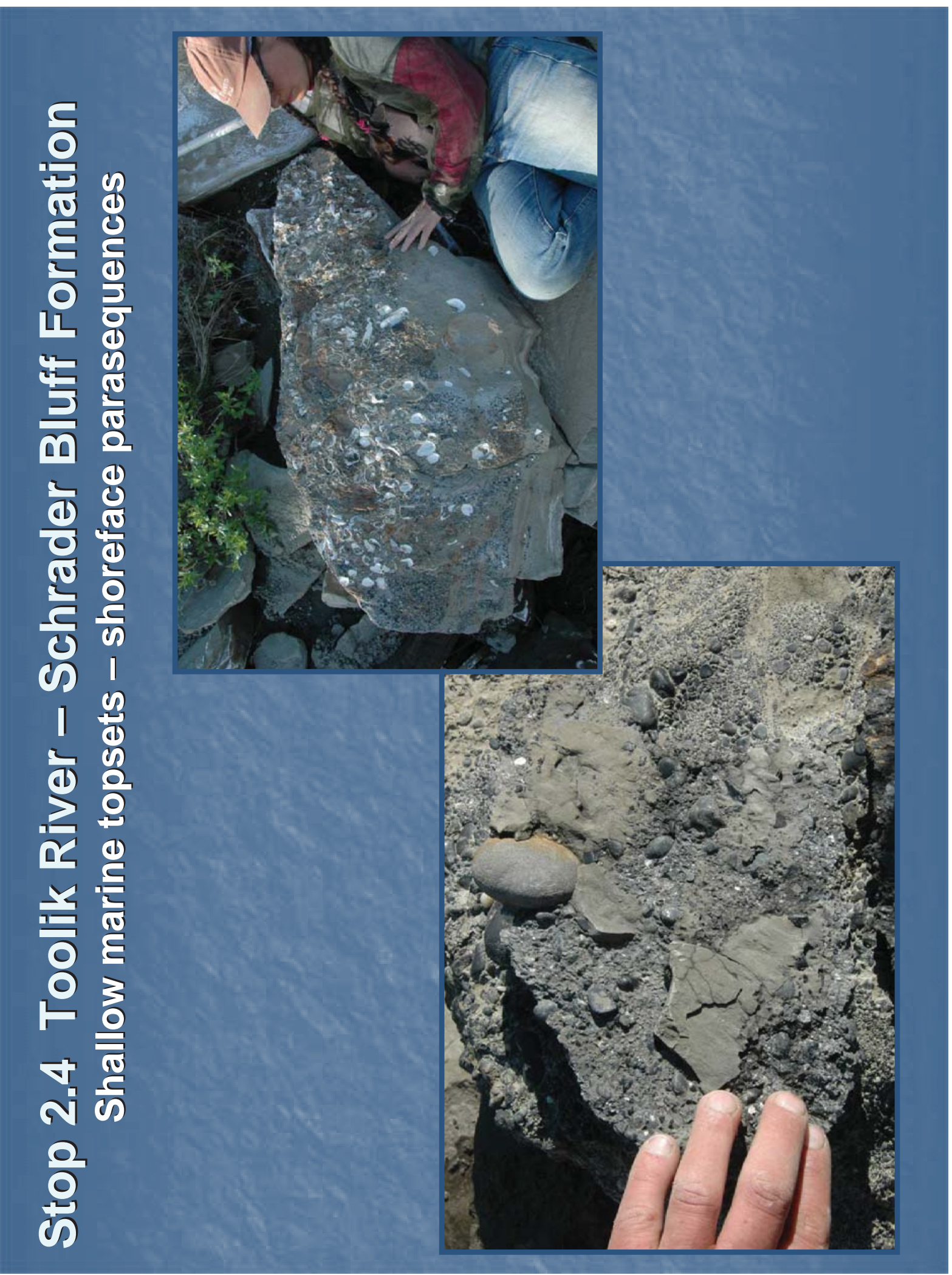




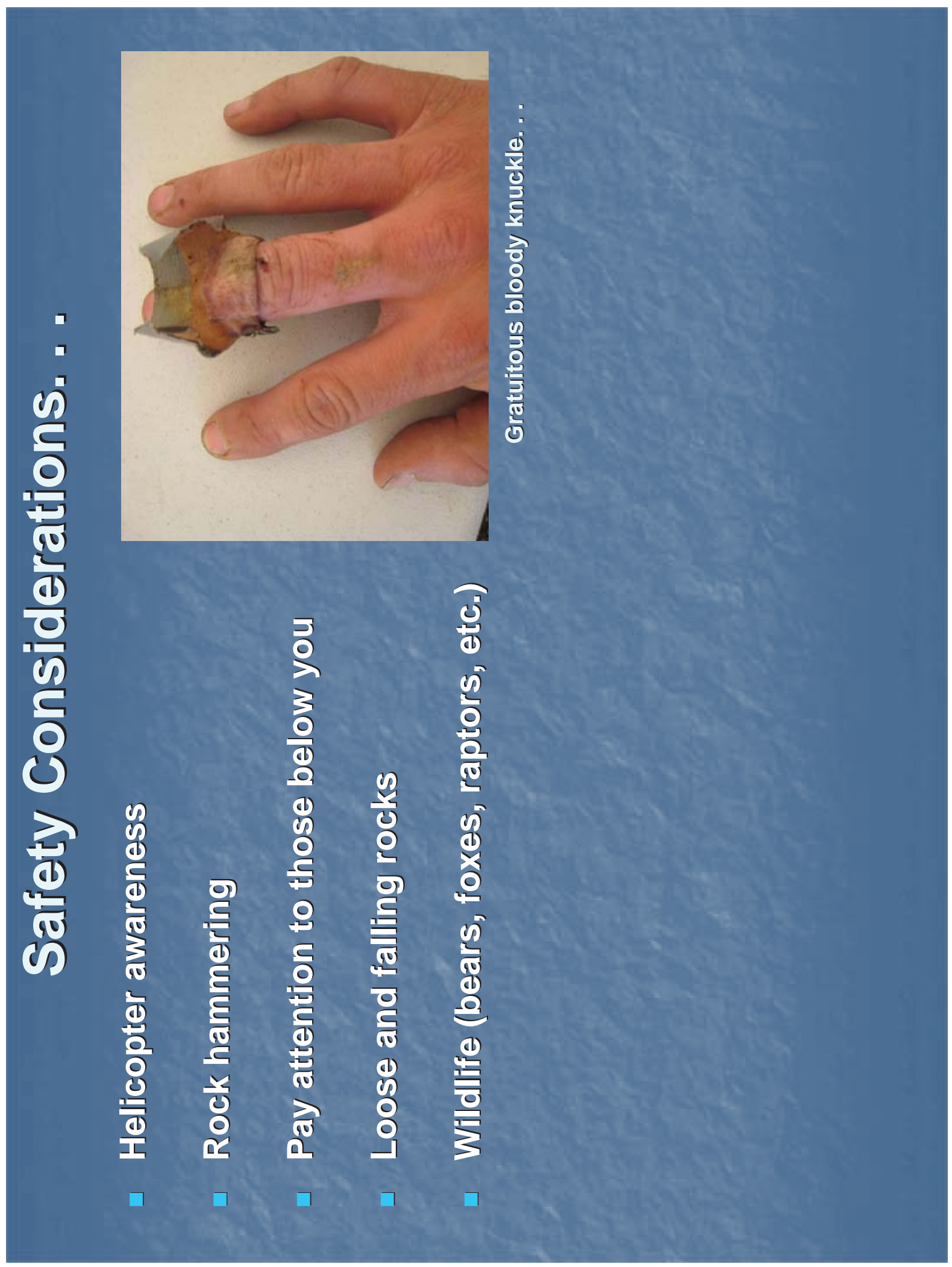




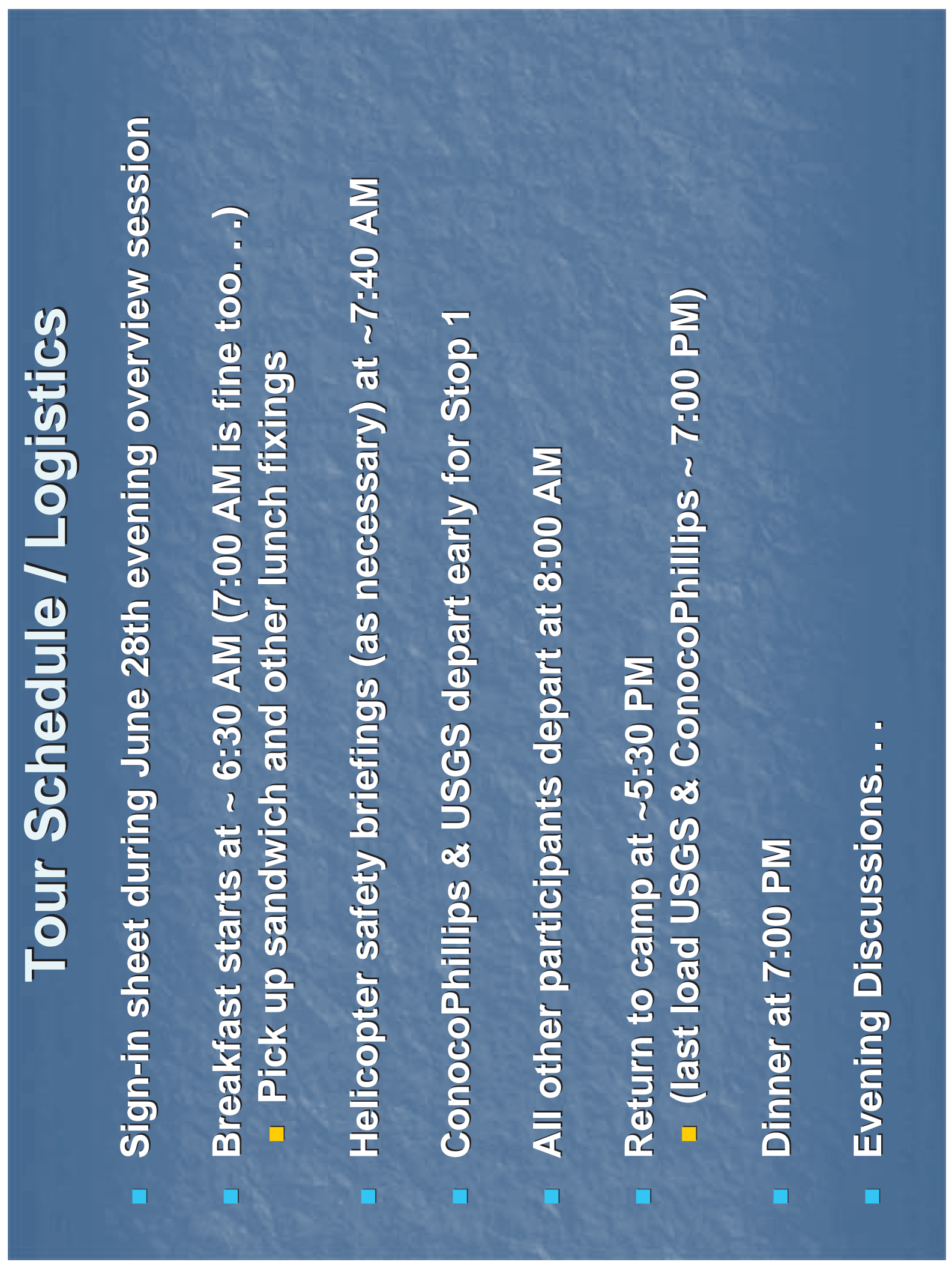




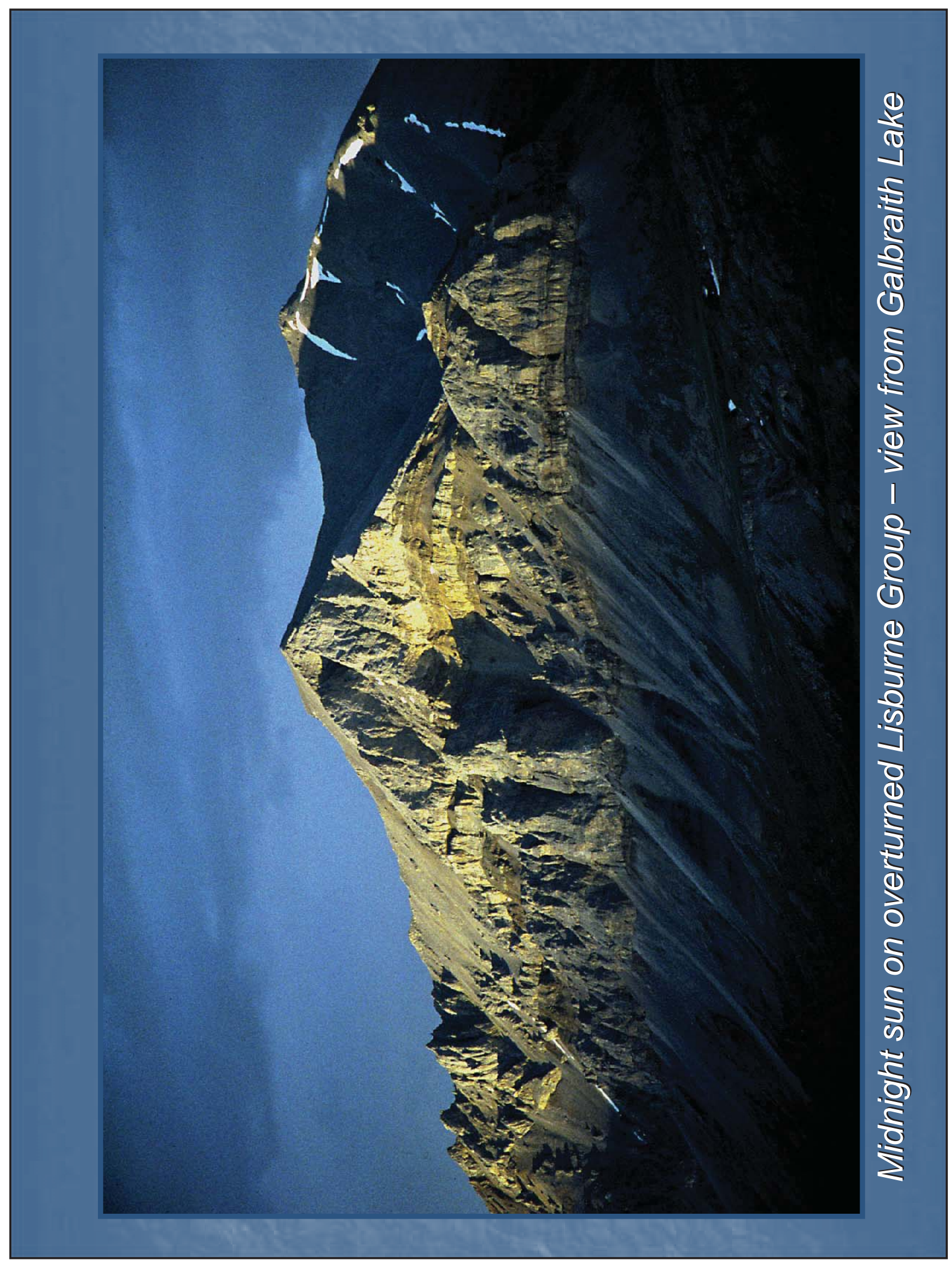




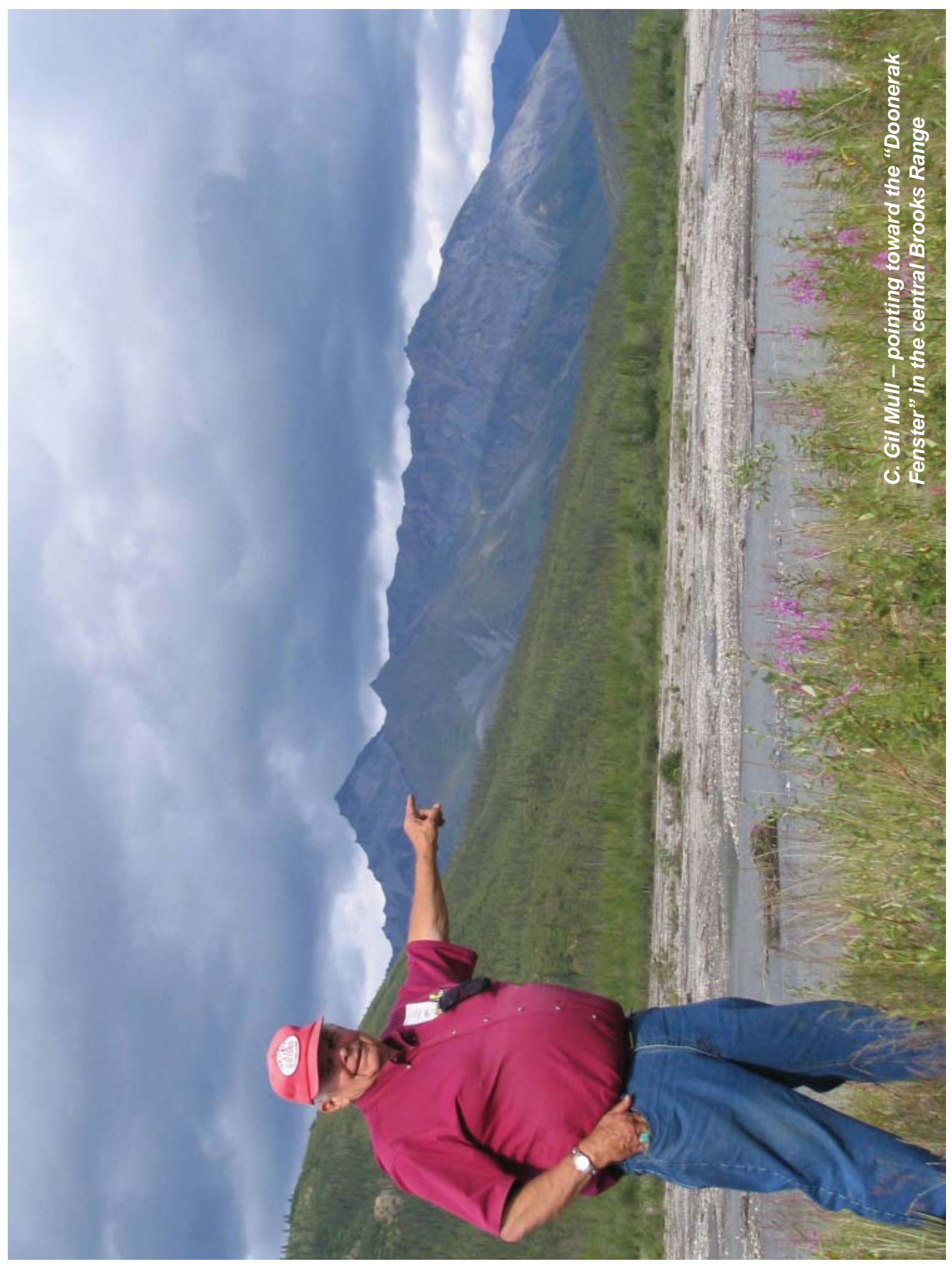

